\title{
INSURANCE LAW PRINCIPLES \\ IN AN INTERNATIONAL CONTEXT: \\ Compensating Losses CaUsed by Climate Change
}

\author{
CRAIG BROWN AND SARA SECK*
}

This article examines the challenges of paying for loss caused by climate change. It discusses how weatherrelated harms might become uninsurable by private companies in the future as the adverse effects of climate change increase in severity. Additionally, this article recognizes the difficulty in imposing civil liability on wrongdoers for climate-related harms, and explores options for state-sponsored or state-subsidized insurance. Finally, the authors examine possibilities for an international insurance fund, but eventually conclude that such a fund would unlikely be endorsed at the international level and would not benefit Canadians.
Cet article porte sur les défis que le fait de payer les pertes causées par le changement climatique. Il examine notamment la manière dont les dommages causés par le climat pourraient ne plus être assurables à l'avenir par les entreprises privées, alors que les effets indésirables du changement climatique continuent de s'aggraver. De plus, cet article reconnaît la difficulté d'imposer une assurance civile à l'égard des auteurs de méfaits pour les dommages reliés au changement climatique; l'article examine les options d'une assurance offerte sous l'égide d'État ou subventionnée par celui-ci. Enfin, l'auteur examine la possibilité d'une caisse de prévoyance internationale, mais arrive à la conclusion qu'une telle caisse ne serait probablement pas acceptée sur le plan international et ne profiterait pas aux Canadiens.

\section{TABLE OF CONTENTS}

I. INTRODUCTION . . . . . . . . . . . . . . . . . . . . . . . . . . . . . . . . . . . . . . . 542

II. INSURANCE AND ClimATE CHANGE . . . . . . . . . . . . . . . . . . . . . 544

III. THE NATURE AND PURPOSE Of INSURANCE LAW . . . . . . . . . . . . . . . . . 545

IV. LIABILITY INSURANCE . . . . . . . . . . . . . . . . . . . . . . . . . . . 547

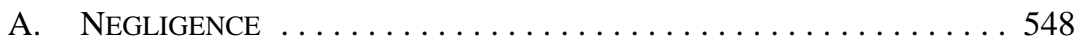

B. NUISANCE . . . . . . . . . . . . . . . . . . . . . 550

V. Climate Change AND Insurance LAW . . . . . . . . . . . . . . . . . . 550

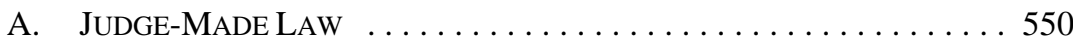

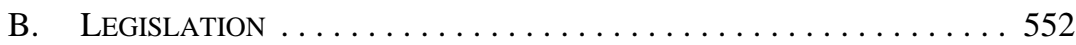

VI. A FEW HistoricAl PRECEDENTS . . . . . . . . . . . . . . . . . . . . . . . . . . 553

A. Fire INSURANCE . . . . . . . . . . . . . . . . . . . . . 553

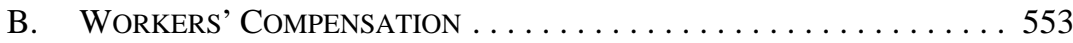

C. Automobile Accidents . . . . . . . . . . . . . . . . . . . 555

D. NATURAL DisAster INSURANCE IN NEW ZEALAND $\ldots . . \ldots \ldots . . .556$

E. BRITISH COLUMBIA DiSASTER FINANCIAL

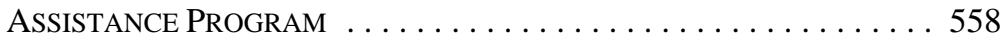

F. UNITED STATES FEDERAL EMERGENCY

MANAGEMENT AGENCY . . . . . . . . . . . . . 559

VII. InTERNATIONAL LAW, ClimATE, AND CANADA . . . . . . . . . . 561

A. RESPONSIBILITY AND LIABILITY IN INTERNATIONAL LAW . . . . . . 563

B. CANADA AND THE INTERNATIONAL CLIMATE REgIME $\ldots \ldots \ldots . . .569$

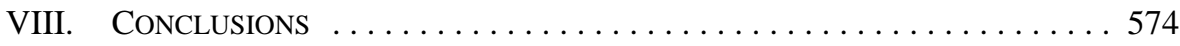

Faculty of Law, Western University. The authors wish to thank Borden Ladner Gervais LLP for their generous support of this project through their Research Fellowship program and research assistants Alexandra Hurd, Vera Dokter, and Julius Ko. 


\section{INTRODUCTION}

Anthropogenic climate change presents serious challenges, not least the problem of paying for the losses it causes. In this article we examine this problem and consider possible solutions, recognizing at the outset the complexities involved, such as the difficulty of establishing cause and effect in individual cases and the international scope of the problem.

There can be no doubt there is a problem. In 2007, the Intergovernmental Panel on Climate Change (IPCC), consisting of 93 contributing authors from 18 countries, ${ }^{1}$ examined the likely effects of anthropogenic greenhouse gas (GHG) emissions on the world's climate. ${ }^{2}$ Using several models, taking into account differences between them, ${ }^{3}$ the panel predicted that the global mean surface temperature will increase over the next century, most likely by about $3^{\circ} \mathrm{C}$. ${ }^{4}$ There is significant consensus that this warming is caused by, and will be proportional to, anthropogenic GHG emissions. ${ }^{5}$ Expected effects are that heat waves will become more intense and frequent, intense precipitation and droughts will increase, and glaciers, ice caps, and permafrost will decrease, contributing to sea level rise. Resultant effects on the climate include more frequent and more severe floods, tornados, hurricanes, and blizzards. ${ }^{6}$

As the risks of these events both increase and become more unpredictable, insurance against them will become less widely available. Indeed, it is possible that weather related harms may become uninsurable in the future as the adverse consequences of climate change increase in severity. ${ }^{7}$ Liability insurance will be of limited utility because underlying tort actions will be problematic, owing to difficulties in connecting the activities of specific defendants to harm suffered by specific plaintiffs. This is compounded by the fact that the cause and effect, in so far as it can be identified at all, occurs across international boundaries. This in turn will make traditional insurance even more problematic because it will reduce the chances of recouping losses through subrogation. ${ }^{8}$

It is true that these problems may be mitigated in various ways, at least in part. Reinsurance allows insurers to spread risks by insuring themselves against the financial

Represented countries include: the United States, Switzerland, France, Belgium, Senegal, the United Kingdom, Japan, Australia, Canada, China, Russia, Germany, Sweden, New Zealand, the Netherlands, Monaco, Finland, and India.

2 Gerald A Meehl et al, "Global Climate Projections" in S Solomon et al, eds, Climate Change 2007: The Physical Science Basis - Contribution of Working Group I to the Fourth Assessment Report of the Intergovernmental Panel on Climate Change (Cambridge: Cambridge University Press, 2007) 747. Ibid at 749 .

Ibid.

Ibid. See also "A New Assessment of Global Warming,” online: Berkeley Earth Surface Temperature <http://berkeleyearth.org/study/>; “Dr. Muller’s Findings,” Editorial, The New York Times (3 November 2011), online: The New York Times <http://www.nytimes.com/2011/11/04/opinion/dr-mullers-findings -on-global-warming.html>.

$6 \quad$ Meehl et al, ibid at 750-51.

Ibid. See also Evan Mills, “Insurance in a Climate of Change,” (2005) 309 Science 1040; Evan Mills, Richard J Roth, Jr \& Eugene Lecomte, “Availability and Affordability of Insurance Under Climate Change: A Growing Challenge for the United States” (2006) 25:2 Journal of Insurance Regulation 109; "Environment," online: Lloyd's <http:/www.lloyds.com/Lloyds/Corporate-Responsibility/Environ ment>.

8 Subrogation, as it applies to insurance law, ensures that (a) insurance claimants do not recover more than the value of their losses by allowing insurers, rather than the claimants themselves, to exercise any rights, such as tort rights, against third parties; and (b) negligent causers of harm do not escape liability. See Craig Brown, Insurance Law in Canada, 7th student ed (Toronto: Carswell, 2010) ch 13 [Brown, Insurance Law]. To the extent subrogation operates in relation to environmental claims, it reinforces the “polluter pays" principle. 
stresses caused by having to pay a large number of claims in a short time, such as those arising from a major hurricane. Reinsurance companies are typically international in the scope of their business, so the risks are spread globally. A relatively recent alternative mechanism by which insurers have begun to spread risks is catastrophe bonds. These bonds, typically issued by insurers, provide investors with attractive returns, but which are forfeited in the event of a specified catastrophe such as a major flood or hurricane. ${ }^{9}$ As major weather events increase in frequency and severity, however, reinsurers can be expected to respond by raising premiums and reducing the scope of risks they are prepared to cover, ${ }^{10}$ and investors are likely to become less prepared to buy catastrophe bonds.

If the private insurance market cannot adequately provide protection against the financial consequences of major weather events, the alternative is that it be provided by government, or at least some form of public-private partnership. In some countries, government programs have been created to deal with risk environments too volatile for the private insurance industry to handle by itself, if at all. In some, premiums for private insurance are subsidized. In others, such as those operated by the New Zealand Earthquake Commission and the British Columbia Disaster program, government agencies are the insurers. In either case, the cost of providing compensation is subsidized by taxpayers.

In this article, we will first outline how climate change is expected to impact Canadian insurers, and their anticipated response. Second, we will explore the first principles that inform the nature and purpose of insurance law. Third, we will outline the relationship between tort law and liability insurance and examine the complications that arise in the climate context. Next, after briefly addressing how judges and legislators could respond to the climate and insurance problem, we will provide examples of public law models of insurance, including fire insurance, workers' compensation insurance, automobile insurance, as well as natural disaster insurance examples from New Zealand, the United States, and British Columbia.

Having concluded that there is a role for government involvement in a public insurance scheme to address climate related harms in Canada, we will turn to international law in order to determine whether it would be possible, first in theory and then in practice, for an international climate compensation fund to contribute to domestic state public insurance schemes in the climate context. While this part will demonstrate that such a fund is possible in theory, we will conclude that not only would this approach be unlikely to be endorsed at the international level, but also that it would ultimately be unhelpful for the Canadian climate insurance problem. Instead, we will conclude by offering a range of possible proposals for future consideration.

10 WJW Botzen \& JCJM van den Bergh, "Insurance Against Climate Change and Flooding in the Netherlands: Present, Future, and Comparison with Other Countries” (2008) 28:2 Risk Analysis 413 at 421. 


\section{INSURANCE AND Climate ChANGE ${ }^{11}$}

In 2000, Angus Ross listed the following consequences of climate change for Canada that would have implications for insurers: ${ }^{12}$

- $\quad$ There will be more frequent extreme "precipitation events," such as tornadoes and hail occurring in more places. Whereas such an event was previously expected to happen once in 80 years, it would, with the onset of climate change, be expected to happen every ten years.

- $\quad$ There will be more droughts and more floods (among the consequences of which will be increased pollution from such events as leakage from oil tanks and runoff from farms). There will also be a greater frequency of windstorms, with increases in wind loads.

- The Northwest Passage will be open to significantly greater volumes of traffic, possibly as much as 30 vessels a day. On the other hand, lower water levels in the Great Lakes will create new shipping hazards of grounding.

- $\quad$ Forest fires will occur more frequently.

- $\quad$ Disease will increase in that there will be more respiratory disorders, tropical diseases will migrate northward, and there will be more water contamination by parasites, bacteria, and protozoa.

- The elimination of the permafrost in the north will create a freezing-thawing cycle that will impact oil and gas lines and building foundations, and the elimination of ice highways will make transportation and repairs more costly.

- Milder winter weather will result in more use of motor vehicles, particularly motorcycles. ${ }^{13}$

In this section we discuss climate change in relation to first party insurance. For a discussion of implications for liability insurance, see Jeffrey W Stempel, "Insurance and Climate Change Litigation" in William CG Burns \& Hari M Osofsky, eds, Adjudicating Climate Change: State, National, and International Approaches (Cambridge: Cambridge University Press, 2009) 230 at 230ff. For liability insurance considerations to be relevant, tort law has to be viable as a means of obtaining compensation for climate-related harms. As discussed below, this is unlikely in Canada.

12 Angus H Ross, "Reflections on the Future - Climate Change and its Impacts on the Insurance Industry" (9 June 2000), online: Institute for Catastrophic Loss Reduction <http://www.iclr.org/images/2000_ June_AngusRoss_Presentation.pdf $>$. See also Meehl et al, supra note 2.

13 For additional and more recent, but consistent, analyses, see "The vanishing north: There are benefits in the melting of the Arctic, but the risks are much greater,” The Economist 403:8789 (16 June 2012) 13, online: The Economist <http://www.economist.com/node/21556921> ["The Vanishing North”]; Chris Furgal \& Terry D Prowse, "Northern Canada” in Donald S Lemmen et al, eds, From Impacts to Adaptation: Canada in a Changing Climate 2007 (Ottawa: Natural Resources Canada, 2008) 57; Quentin Chiotti \& Beth Lavender, “Ontario” in Lemmen et al, ibid, 227; Liette Vasseur \& Norm R Catto, “Atlantic Canada” in Lemmen et al, ibid, 119; Blair Feltmate \& Jason Thistlethwaite, Climate Change Adaptation: A Priorities Plan for Canada (Waterloo: University of Waterloo, 2012), online: Adapt Now Canada <http://www.adaptnowcanada.ca/report/>; Michael V'inkin Lee, "Climate change to bring more severe wildfires to B.C.: report,” The Vancouver Sun (7 June 2012), online: The Vancouver Sun <http://www.vancouversun.com/news/Climate+change+bring+more+severe+wildfires+ report/6748 403/story.html>; Daniel-Stefan Paraschiv, "Insurance Against Losses from Natural Disasters" (2011) 3:2 Contemporary Readings in Law and Social Justice 224; "Climate change concerns 
All this will affect insurance. There are obvious implications for insurance on property, including buildings, ships and cargo, forests, oil and gas pipelines, motor vehicles, and crops. Flood insurance, where available (while commonly excluded in homeowners policies, flood is usually covered under "all risk" commercial policies) will be more expensive. Various forms of liability insurance will also be affected. Farmers will face greater exposure to liability for fecal and chemical runoff after floods, engineers and builders will be subject to higher standards in respect to the design and construction of buildings, and motorists and motorcyclists will have greater exposure to liability on the roads. ${ }^{14}$ There will be increased exposure for credit risks (surety and guarantee insurance) because construction projects, for example, face a greater likelihood of weather-related delays or cancellation. Further, present conceptions of "catastrophe" will be challenged in that the occurrence of a "continuous event" of, say, 72 hours (typically necessary to trigger catastrophe insurance), will become commonplace. ${ }^{15}$ Life, health and accident, and sickness insurance will also be affected. Death, disease, or disability from climate-related causes will increase. Without relevant exclusions, this will increase insurers' exposure. All of this will demand new approaches to underwriting. ${ }^{16}$

While overall it can be predicted with a degree of confidence that, assuming the validity of scientific predictions, this alarming increase in risk will occur, the precise rate of increase in the occurrence of particular hazards in any given year remains unpredictable, and unpredictability of risk is what insurers fear most. When faced with unpredictability, they assume the worst and price accordingly, or decline to cover that hazard at all. Therefore, insurers' response to all these predicted consequences of climate change will be either to cease covering particular hazards entirely, or at the least to increase premiums. ${ }^{17}$

\section{The Nature AND Purpose of InSURANCE LAW}

These choices (whether to insure and what premiums to charge) are not only permitted by insurance law, they are encouraged by it. At the heart of all insurance law is the notion that insurance is about the transfer of risk. People facing the prospect (but not the certainty) of specified kinds of loss are provided protection from the financial consequences of such loss should it occur. To the extent insurance is created by contract, this distinguishes insurance from other types of contracts and explains numerous rules peculiar to insurance law. Given two basic facts in play - potentially devastating loss to the insured and the uncertainty of

raised by insurance industry,” CBC News (23 February 2012), online: CBC News <http://www.cbc.ca news/canada/new-brunswick/story/2012/02/23/nb-climate-change-insurance-836.html >; Peter Sinclair, "Insurance Companies Feeling the Effects of Climate Change,” The Oil Price (12 December 2011), online: OilPrice.com <http://oilprice.com/The-Environment/Global-Warming/Insurance-CompaniesFeeling-The-Effects-Of-Climate-Change.html>.

14 At present, pricing of motorcycle insurance is based on the assumption that the vehicle will be used for seven to eight months a year only.

15 See Ernst Rauch, “Effects of Climate Change on the Insurance Industry” (2007) 43(A) Stan J Int'l L 239.

16 Christina Ross, Evan Mills \& Sean B Hecht, "Limiting Liability in the Greenhouse: Insurance RiskManagement Strategies in the Context of Global Climate Change” (2007) 43(A) Stan J Int’l L 251.

For the view that insurers are exaggerating these concerns to justify high premiums and government assistance, see J Robert Hunter, "Property/Casualty Insurance in 2008: Overpriced Insurance and Underpaid Claims Result in Unjustified Profits, Padded Reserves, and Excessive Capitalization” (10 January 2008), online: Consumer Federation of America <http://www.consumerfed.org/elements/www. consumerfed.org/file/finance/2008Insurance_White_Paper.pdf $>$. See also "Climate blamed in insurance losses,” CBC News (3 January 2011), online: CBC News <http://www.cbc.ca/news/business/story/ 2011/01/03/insurance-losses-climate-change.html>. 
its happening - it has been thought necessary to include in insurance law several unique rules. In general terms, it can be said that the purpose of insurance law is to strike an appropriate balance between the interests of those who face or have suffered loss and the interests of the organizations, public or private, whose role is to provide insurance against that loss. That is easy enough to see in the law relating to insurance contracts. Once insurer and insured have consented to contractual relations, the law's role is to mediate between the possibly conflicting reasonable expectations each party has arising from the contract. But this is limited to those circumstances where there is a contract. Where there is no contract, say because the insurer refuses to accept the prospective insured's offer, a narrow concept of insurance law has nothing more to provide.

Accordingly, if insurers choose not to offer certain types of coverage because climate change has made them unprofitable, people who face losses no longer covered will not be protected by insurance law (so defined) because it simply does not apply. However, at least in Canada, some insurance law, almost always in the form of legislation, has the purpose of making sure that coverage is available for certain types of loss when, left to the market and private contract law, it might not be available to some or even all who need it. In other words, some insurance law addresses not only the transfer of risk when it happens, but also mandates that the risk be transferred and creates mechanisms by which this is possible.

Thus, if a legislature so desired, insurance law could be created to require that insurance be made available where an unregulated market would not provide it. But a legislature is unlikely to impose upon insurers obligations to provide specific coverage at a specific premium without regard to realistic actuarial considerations. If the predictions mentioned previously hold true and certain types of catastrophic loss become uninsurable according to the principles of private insurance, mandatory provisions of coverage for inadequate premiums would be a recipe for financial calamity. Even mandated coverage must comply with basic insurance business principles.

Not surprisingly, these principles of insurance are reflected in the principles of insurance law. ${ }^{18}$ Among these is the principle of fortuity. Insurers can provide protection against the financial consequences of loss for a fraction of the value of that loss because they afford similar protection to multiple insureds knowing that loss is going to happen to a relative few of them, and it is not known in advance which of them will suffer loss. The key is the randomness of loss in terms of when it happens, to whom it happens, and its extent.

Insurance law seeks to uphold the fortuity principle, and thereby assist the continuing viability of insurers, primarily through rules pertaining to the interpretation of insurance policies. For example, it is presumed that an insurance contract is not intended to provide for circumstances where the loss is brought about deliberately by the insured person. Most often this notion is given effect in disputes about the meaning of "accident" or "accidental" in policy wording. ${ }^{19}$ But it is not necessary for a policy specifically to restrict coverage to unintentional conduct for the fortuity principle to apply. It is a presumption that can only be

18 See Brown, Insurance Law, supra note 8 at ch 1.

19 See e.g. Canadian Indemnity Co v Walkem Machinery \& Equipment Ltd, [1976] 1 SCR 309; Cooperative Fire \& Casualty Co v Saindon, [1976] 1 SCR 735. 
overridden by express language. It is also presumed that the parties to an insurance contract intend that there be no coverage where the loss is certain to happen, as in the case of normal wear and tear to property or other inevitable damage. ${ }^{20}$ Even life insurance triggered by death, the quintessential inevitability, operates on the fortuity principle because the time of death is uncertain.

As the likelihood of potential loss becomes less uncertain, insurers respond in one or both of two ways. They limit coverage through more restrictive insuring agreements or wider exclusions (or, indeed, withdraw from the particular type of coverage entirely) or they increase premiums. Without specific legislation to the contrary, insurance law permits this. When the tighter market is judged to be sufficiently problematic in social terms, there is pressure for new legislation, either to regulate insurers' pricing policies, for direct government involvement in the supply of insurance, or for changes to insurance and related compensation law. ${ }^{21}$

Paradoxically, the same outcomes arise when loss becomes too uncertain in the sense that its frequency and severity defy a degree of predictability with which underwriters are comfortable. In these circumstances, costing assumptions and other underwriting decisions are based on worst-case scenarios. It is assumed that loss will happen often and will always be severe. In other words, highly unpredictable loss is treated as if it is almost certain.

Another principle of insurance law is consumer protection. This is reflected in legislation and regulation as well as judge-made rules. In the end, though, if insurers in the private market cannot make it work because of the prevailing risk environment, "consumers" (those facing the risk and needing coverage) are not protected. This is where other solutions become necessary and "insurance law" assumes a larger dimension.

\section{LIABILITY INSURANCE}

In some circumstances, liability insurance may provide funds to compensate climate related loss. This would occur when a person holding liability insurance is sued successfully for causing or contributing to the loss suffered. In the context under consideration here, that would mean the insured defendant has caused a climate effect which has in turn caused the loss. That requires that the plaintiff has been able to successfully argue that the elements of a tort exist. The most likely candidates are negligence and nuisance. Where an insurer can show that the insured acted intentionally (including imputed intent), it will usually be permitted to deny payment. This may be because of an operative exclusion clause or, more generally, because the loss was not, from the insured's perspective, fortuitous. In Robinson v. Evans Bros Pty Ltd., ${ }^{22}$ the harm to a market gardener's crops from the pollution emitted by an adjacent brick factory was held not to have been caused "accidentally" for purposes of liability insurance coverage. In effect, intention to cause the harm was imputed to the defendant. It is also possible in such cases to argue that the invasion of noxious substances 
is both direct and physical. ${ }^{23}$ But any connection that can be established between a GHG emitter, or even a group of them, and illness, personal injury, or property damage suffered by a plaintiff or class of plaintiffs, is clearly indirect. Therefore, even if the result can be shown to have been so highly likely as to invoke imputed intent, and even if the impact can be characterized as a physical invasion, an action in trespass is unlikely to be successful. ${ }^{24}$

\section{A. Negligence}

Given increasing evidence connecting certain kinds of pollution to climate change, it is not implausible to claim that this connection is reasonably foreseeable from the standpoint of polluters. Failure to take reasonable precautions to prevent or reduce foreseeable harm is negligence. However, that alone does not mean that a plaintiff or class of plaintiffs could easily succeed in a negligence action against a polluting defendant. A successful action requires the plaintiff to establish that the defendant owed him or her a duty of care, that the duty was breached, that the breach of duty caused the harm, and that the harm was not too remote. Each of these requirements represents a significant obstacle in the context of potential climate change litigation.

\section{DUTY}

In Canada, the duty of care upon which a negligence action is founded is defined by a three-part test. First, it must be reasonably foreseeable from the defendant's point of view that negligent performance of an activity could result in harm to the plaintiff. Second, there must be a degree of proximity between the defendant and plaintiff such that it is fair and reasonably predictable that negligently caused harm would result in legal liability. Third, imposition of a duty should not produce negative consequences for society that, as a matter of policy, outweigh the benefits of liability. ${ }^{25}$

As mentioned, a court might accept that contribution to climate change is a foreseeable result of certain pollution producing activities. It is a different matter whether the court would regard a person engaged in such an activity as "proximate" to a person who suffered harm because of climate change. The principal indicator of proximity in this sense is whether the posited duty falls within, or is analogous to, a category of duty that has been previously accepted by the courts and therefore predictable by potential defendants. While liability in negligence is already recognised where a defendant contaminates the property of another, ${ }^{26}$ harm of the kind associated with climate change (given the way it arises) is arguably in a different category. Although concerns about the appropriateness of liability might more correctly be addressed under the headings of policy, causation, or remoteness, a court could, for the same reasons, simply declare that the parties are insufficiently proximate.

See e.g. Kerr v Revelstoke Building Materials Ltd (1976), 71 DLR (3d) 134 (Alta SC).

The directness requirement would be avoided if a court accepted an argument, based on the old action of trespass on the case, that harm indirectly but intentionally caused is actionable. See e.g. Wilkinson $v$ Downton, [1897] 2 QB 57, involving intentional infliction of nervous shock. However, trespass on the case has now been almost wholly subsumed within the negligence action.

See generally Cooper v Hobart, 2001 SCC 79, [2001] 3 SCR 537.

See e.g. Ball v Imperial Oil Resources Ltd, 2010 ABCA 111, 477 AR 251; Bingley v Morrison Fuels, 2009 ONCA 319, 95 OR (3d) 191. 
Even if the tests of both foreseeability and proximity are met, a court may still decline to recognize a duty on broad policy grounds. Liability in negligence for pure economic loss is limited in Canada primarily because of concerns about indeterminate liability. ${ }^{27}$ This reflects a policy choice about loss allocation. It is deemed inappropriate to saddle a defendant with potential liability "in an indeterminate amount for an indeterminate time to an indeterminate class.” ${ }^{28}$ Given the scale on which climate change and its effects occur, this is a concern that might well find traction in climate change litigation.

\section{STANDARD OF CARE}

A plaintiff suing in negligence for climate change related harm would have to establish that the defendant had been negligent. This means it must be shown that there was some conduct or omission falling below a standard that could reasonably be expected of the defendant in the circumstances. This might be a challenge. One could expect arguments from defendants that compliance with industry standards and/or relevant environmental regulations reflects reasonable conduct. Moreover, elimination of emissions may mean such high costs, not only to the emitter but also to the wider community in the form of job losses and the economic ripple effects, that it would be unreasonable not to continue as before. ${ }^{29}$

\section{CAUSATION}

Perhaps the most difficult issue confronting a plaintiff in a negligence action would be causation. The plaintiff would have to prove, on the balance of probabilities, that but for the defendant's negligence, the harm would not have happened. Although there is a consensus that human activity contributes to climate change, there is uncertainty about how this activity interacts with natural phenomena. As the human contribution to climate change is a collective effort, it is effectively impossible to prove a connection between an individual defendant's activity and harm suffered by an individual plaintiff or even class of plaintiffs. ${ }^{30}$ Even the concept of "material contribution," which is sometimes used by courts to establish a causal link when the "but for" test is inadequate, ${ }^{31}$ would not likely assist in climate change cases. Again, the difficulty would lie in establishing just how much an individual emitter has materially increased the risk of harm.

\section{REMOTENESS}

If factual causation is established, it is still necessary to confront the legal question of whether the causal link is too attenuated for liability to be appropriate. If the harm is judged

$\begin{array}{ll}27 & \text { See e.g. Hercules Managements Ltd v Ernst \& Young, [1997] } 2 \text { SCR } 165 . \\ 28 & \text { Ultramares Corp v Touche (1931), } 174 \text { NE } 441 \text { (NYCA) at } 444 .\end{array}$

29 The so-called "Hand formula" posits that conduct is not negligent where the cost of prevention of harm produced by the conduct, including the loss of social benefit, outweighs the risk of harm. See United States v Carroll Towing Co, 159 F 2d 169 (2d Cir 1947). C.f. Bolton v Stone, [1951] AC 850 (HL).

$30 \quad$ See David A Grossman, “Tort-Based Climate Litigation” in Burns \& Osofsky, supra note 11, 193 at 217 [footnote omitted]. The author puts it this way:

The complexity of the climate system means that several factors are involved in producing shifts in climatic activity, such as more intense storms or higher temperatures, which are also subject to natural fluctuations. These multiple causes and background levels of climatic effects make it difficult to show that defendants' contributions to anthropogenic climate change caused any particular incidence of a phenomenon.

31 See Resurfice Corp v Hanke, 2007 SCC 7, [2007] 1 SCR 333. 
to be too remote from the defendant's negligence, there is no liability. The modern test employed in Canada is whether the harm is reasonably foreseeable in the sense that it would be regarded by a reasonable person as a "real risk" and not dismissed as "far-fetched." 32 It could be argued that, given the publicity surrounding climate change, it is not far-fetched to expect that greenhouse gas emissions could lead to climate-related damage. But this is at a level of generality. Linking a specific defendant with a specific plaintiff might well be considered too speculative to be foreseeable, even under the modern approach.

\section{DEFENCES}

At least for some types of harm, a defendant could reasonably argue that the plaintiff's negligence had contributed to the loss. Building a house at a location known to be vulnerable to floods or hurricanes is an example. In Canada, this would amount to a partial defence resulting in a reduction of damages. A defendant might also be able to invoke the defence of inevitable accident. ${ }^{33}$

\section{B. NUISANCE}

Where a person suffers unreasonable interference with the enjoyment of his or her property, he or she may sue in private nuisance. ${ }^{34}$ Interference is unreasonable if the harm done outweighs the utility of the conduct causing it. As with negligence, reasonableness turns on a cost-benefit analysis. In nuisance, as in negligence, a plaintiff alleging that a defendant caused climate related harm would be confronted with the defendant's claim that his or her or its conduct provided benefits, such as jobs and other economic advantages, which outweighed the harm to the plaintiff. Also in common with negligence, the plaintiff(s) would have the problems of proving causation and countering defences such as contributory negligence. ${ }^{35}$

\section{Climate Change and Insurance LaW}

Assuming the scientific predictions about climate change and its physical effects are accurate, and taking at face value insurers' concerns about the consequences of this for assessing and pricing risk, what might be the response of insurance law, both judge-made and legislation (but especially the latter)?

\section{A. JUDGE-MADE LAW}

Historically, the thrust of judge-made law relating to insurance has been the protection of insurers' solvency. This explains the principles of fortuity, indemnity, and, to a significant

\footnotetext{
32 See Mustapha v Culligan of Canada Ltd, 2008 SCC 27, [2008] 2 SCR 114 at para 13.

See Rintoul $v$ X-Ray and Radium Industries Ltd, [1956] SCR 674.

Public nuisance may also be available if the plaintiff has suffered "special damage" from an activity that has affected the community generally. Most often, actions in public nuisance are brought by public authorities with the principal objective being an injunction. For discussion of public nuisance in relation to climate change in the US, see Ken Alex, "A Period of Consequences: Global Warming as Public Nuisance” (2007) 43(A) Stan J Int’l L 77; Grossman, supra note 30.

35 See Allen M Linden \& Bruce Feldthusen, Canadian Tort Law, 9th ed (Markham: LexisNexis, 2011) ch 15.
} 
extent, utmost good faith. In the face of the challenges expected to arise from climate change, the concern about financial viability will be paramount. In consequence, the concepts of fortuity, indemnity, and the insured's duty of disclosure will assume even greater importance. But this will mean the application of existing law as opposed to the creation of new law.

In the early 1700s the conditions of the marketplace for insurance, notably the practical difficulties underwriters had in obtaining accurate information relevant to prospective risks, impeded the efficient transfer of risk in respect of marine adventures. To rectify this, Lord Mansfield fashioned the rule of utmost good faith. ${ }^{36}$ Without citing a single precedent (unless one counts a quote from Cicero), and referring only to one statute, the Statute of Frauds ${ }^{37}$ (which had no direct application to the case), he simply declared that contracts of insurance were subject to a rule requiring applicants for insurance to disclose to underwriters all facts material to risks for which protection was sought. He said this derived from the "principles of natural equity, [designed] to prevent fraud.,38

The expected consequences of climate change include significant changes to the insurance marketplace in that certain kinds of coverage are likely to disappear or be greatly restricted. This means there is a problem in respect of compensation for loss, perhaps the most important insurance law principle of all. It is hard to see a modern judge creating a new rule, regardless of the absence of precedent, in response to market conditions detrimental to consumers. It is unlikely, for instance, that a case would be decided for a plaintiff simply on the grounds of "natural equity," designed to promote the compensation of a victim of a natural disaster.

There are more subtle ways in which judges may respond to the legal challenges presented by climate change. This is particularly so when it comes to interpreting insurance policies. As described above, Canadian courts already recognize and apply the concept of reasonable expectations when interpreting insurance policies. They also construe coverage clauses more expansively than exclusion clauses. ${ }^{39}$ Consider the example of flood loss: a policy might exclude flood loss or narrow coverage in some other way, such as applying a larger deductible to that category of loss. In such a case, the term "flood" will be interpreted narrowly. In British Columbia v. Royal Insurance Co. of Canada, ${ }^{40}$ the British Columbia Court of Appeal had to interpret the word "flood" in a clause stating that losses resulting from such events were subject to a deductible much greater than for other types of loss. After heavy rain, water overflowed a diversion pipe and damaged partially set concrete being installed to create a permanent channel for a stream. Despite the fact that the policy contained a definition of "flood," which included "the rising of, the breaking out or the overflow of any body of water," ${ }^{41}$ the Court held that the loss in question was not caused by flood. ${ }^{42}$

Cases turning on the interpretation of individual policies, however, rarely reflect a dramatic and permanent change in the law. Insurers can respond by changing the wording

Carter v Boehm (1766), 3 Burr 1905 (KB) [Carter].

1677 (UK), 29 Car II, c 3.

Carter, supra note 36 at 1919.

See Brown, Insurance Law, supra note 8 at ch 8.

(1991), 60 BCLR (2d) 109 (CA).

Ibid at para 7.

Ibid at para 21 . 
of policies to negate, prospectively at least, the effect of an adverse judgment. It is true that, in a fire insurance policy, the new wording may be nullified by a court. ${ }^{43}$ In most Canadian provinces, a court is empowered by legislation to strike down any term of a fire insurance contract it deems to be unjust or unreasonable. ${ }^{44}$ This has been interpreted by the Supreme Court of Canada to allow a court to negate not only a term falling below the required standard, but also a term that, while not unjust or unreasonable on its face, has an unreasonable or unjust effect when applied in a particular case. ${ }^{45}$ However, while it is not impossible that a court, in the aftermath of an extreme climate event causing fire damage, would see denial of a claim as unjust or unreasonable and use this section to negate an exclusion clause entirely, it is surely unlikely.

Still, none of this would represent a fundamental change to insurance law. A change ensuring all the underlying principles of insurance law are maintained would have to come through legislation.

\section{B. LEGISLATION}

As some have suggested, one response to the insurance-related implications of climate change may be greater scrutiny of insurers' accounting processes and more detailed reporting of their costs and loss ratios to ensure that climate change is not used improperly as an excuse to increase premiums. ${ }^{46}$

However, if (assuming that scientific and economic forecasts hold) the private insurance market will indeed be unable to cover the radically increased risks of injury, disease, and especially property damage that climate change will bring, and thus be unable to provide comprehensive and affordable coverage as climate related risks increase, legislation will be needed to establish a compensation scheme to make up for the predicted shortcomings of private insurance. For workers' compensation and insurance for injuries sustained in motor vehicle accidents, Canadian legislatures established new rules and created institutions to give them effect. In some cases they even curtailed the activities of the private insurance industry in order to provide more comprehensive and more affordable coverage. ${ }^{47}$ In other cases, they set up forms of public-private partnerships, such as the British Columbia Disaster Financial Assistance Program. Broadly similar arrangements have been developed in other jurisdictions. As described below, some of these historical precedents provide, if not models, at least a starting point for the discussion.

f a policy insuring property includes coverage against several risks, it will not be covered by the "fire insurance" provisions in the insurance legislation, even if fire is one of the risks covered. See KP Pacific Holdings Ltd v Guardian Insurance Co of Canada, 2003 SCC 25, [2003] 1 SCR 433.

See e.g. Insurance Act, RSA 2000, c I-3, s 545(1).

Marche v Halifax Insurance Co, 2005 SCC 6, [2005] 1 SCR 47 [Marche].

See supra note 17.

See e.g. Insurance (Vehicle) Act, RSBC 1996, c 231; The Automobile Accident Insurance Act, RSS 1978, c A-35. 


\section{Vi. A Few Historical Precedents}

\section{A. FIRE INSURANCE}

It is claimed that in Syria around 1500 B.C. there existed a scheme funded by "public taxation to pay for fire, flood, or drought losses suffered by members of the community."48 In the middle ages in Europe, churches and guilds provided protection in respect of fire, flood, and robbery "through funds raised by collection or assessment." ${ }^{49}$ In Britain (and subsequently North America), this form of insurance became largely a matter for private enterprise. The key event seems to have been the great fire of London in 1666. A property developer involved in the reconstruction of the city offered, as an incentive to purchasers, to rebuild houses if subsequently destroyed by fire again. This idea was so well-received that the developer was encouraged to offer, for a price, the same promise in respect of houses built by others. ${ }^{50}$ The success of this venture led to the establishment of other insurance companies. ${ }^{51}$

The insurance industry accompanied the European settlement of what eventually became Canada. In the face of some company failures and occasional industry malfeasance, government intervention, both federal and provincial, ensued. ${ }^{52}$ This involved measures designed to make sure insurance companies were financially sound, both at creation and on an ongoing basis. Eventually, at the provincial level, there was also detailed intervention in the contractual relationship between insurer and insured. Statutory conditions were imposed on contracts along with other restrictions on freedom of contract, including a provision that no term of a fire insurance contract is binding on the insured if it is deemed by a court to be unjust or unreasonable. ${ }^{53}$

This sequence follows a familiar historical pattern in insurance law. A major event or other development highlights an unprotected risk. Insurance products are developed to address that risk. Problems arise with the market for those products or with the products themselves so that consumers fail to get the protection needed. The legislature, regulators, and/or the courts devise ways to address those problems. In the case of fire insurance, legislative intervention in Canada has yet to take the form of direct government involvement in the market, but in other arenas that has been the response.

\section{B. WORKERS' COMPENSATION}

Workers' compensation, as we know it today, originated in Germany. ${ }^{54}$ Like other forms of financial protection mentioned above in relation to fire insurance, it is traceable to the

SS Huebner, Kenneth Black, Jr \& Bernard L Webb, Property and Liability Insurance, 4th ed, (New Jersey: Prentice Hall, 1996) at 15.

Ibid.

Ibid.

Ibid.

Ontario, Legislative Assembly, Select Committee on Company Law, The Insurance Industry: Third Report on General Insurance (1979) ch 6.

Marche, supra note 45.

See RCB Risk, “'This Nuisance of Litigation': The Origins of Workers' Compensation in Ontario” in David H Flaherty, ed, Essays in the History of Canadian Law (Toronto: University of Toronto Press, 1983) vol 2, ch 8 at 452. 
early guild system that provided disability, sickness, and death benefits funded by contributions from employers and employees. However, when the industrial revolution radically changed the scope and nature of workplace injury, impetus developed for universal, state run protection. In the 1880 s, under pressure from a growing socialist movement, Chancellor Otto von Bismarck introduced a scheme bearing the hallmarks of the system we know in Canada today: compulsory, state run, and financed by employers and workers. ${ }^{55}$

In the late 1800s and early 1900s, common law jurisdictions copied this basic model. Prior to that, compensation for workplace injuries had been left to the law of negligence. An injured worker (or his family in the case of a fatal injury) had to sue his employer, or whoever else caused the injury through negligence. This presented significant obstacles to recovery. First, it was necessary to establish the defendant's fault. It has been suggested that, in Canada, employers were at fault in only a small minority of cases. ${ }^{56}$ Second, even where there might have been some negligence on the employer's part, it is likely a defence would have been available to negate liability. The employer was not liable if the plaintiff was held to have voluntarily assumed the risk that had eventuated. Unlike today, it was a complete defence if the plaintiff had been negligent in a way that contributed to the injury. Similarly, the "fellow-servant rule" held that the contributing negligence of a co-worker also provided the employer with a defence. ${ }^{57}$ Third, there were the practical difficulties of paying legal fees, not to mention medical expenses and daily living costs, pending the outcome of litigation, which could take years. ${ }^{58}$

The result was that many people were exposed to risk without any realistic chance of compensation should the risk manifest itself in injury. The first attempts to deal with this problem reduced the scope of defences to negligence actions. ${ }^{59}$ This was effective in that more than half the actions brought subsequently were successful. ${ }^{60}$ But it provided impetus for more radical change. On the one hand, it remained necessary to prove fault on the part of the employer, so injured workers still faced that hurdle as well as the practical difficulties in mounting litigation referred to above. In other words, as a compensation scheme, it remained far from perfect. On the other hand, employers now faced increased exposure to litigation, both damages and legal costs, motivating them to seek a better system.

This led to legislation not only dealing with tort rules, but also setting up schemes that would actually provide compensation. These differed from jurisdiction to jurisdiction. In Britain, employers were charged with providing limited compensation on a no-fault basis, but workers retained the right to opt instead for a negligence claim if that was to their advantage. ${ }^{61}$ In the US, some states adopted schemes run by a state monopoly, while others charged private insurers with the job. ${ }^{62}$

Ibid.

Ibid at 432-34.

Ibid at 419.

Ibid.

See Employers' Liability Act, 1880 (UK), 43 \& 44 Vict, c 42; The Workmen's Compensation for Injuries Act, 1886, SO 1886, с 28.

Risk, supra note 54.

Workmen's Compensation Act, 1897 (UK), 60 \& 61 Vict, c 37, s 1.

Risk, supra note 54 at 418. 
In Ontario, the Workman's Compensation Act ${ }^{63}$ of 1915 introduced a government run scheme. It was "no-fault" in the sense that workers gave up their right to sue their employers even if the latter were negligent in causing injury. In return, workers were guaranteed compensation for work related injuries without regard to fault. It was funded by employer contributions (varied according to accident experience) and participation was compulsory. The fund was collected and payments administered by a government agency. ${ }^{64}$

\section{Automobile Accidents}

Almost since the advent of the automobile, Canadian legislatures have been tinkering with automobile insurance law to improve the lot of motor vehicle accident victims seeking compensation. Initially this had mostly to do with tort law and its sibling, liability insurance, since these provided the principal means of obtaining compensation in motor vehicle accidents. The burden of proof was reversed in cases where damage or injury was caused by a motor vehicle (other than to another vehicle) ${ }^{65}$ Owners of motor vehicles were made liable for injuries caused by people driving their vehicles with their consent, ${ }^{66}$ and insurers were precluded from relying on lack of privity of contract to deny claims in respect of these cases. ${ }^{67}$ Insurers were also precluded from denying claims merely because the insured people had been in breach of criminal or traffic laws when causing accidents. ${ }^{68}$ Victims of motor vehicle accidents were given direct rights of action against the insurers of motorists whose negligence had caused them injury, even where those insured motorists had acted in breach of the insurance contract. ${ }^{69}$

Not much of this availed an accident victim if the defendant motorist was not insured. Perhaps most significant for the subject of this article, provinces legislated incentives to induce owners of motor vehicles to buy liability insurance. This took the form of penalties imposed on a motorist, not for driving without insurance, but for not having it in the event of an accident she or he caused. ${ }^{70}$ This was supplemented by the creation of publicly administered funds called Unsatisfied Judgment Funds from which payment was made to victims whose injuries were caused by uninsured or unidentified motorists. ${ }^{71}$ The funds were contributed by motorists who, upon registering their vehicles, could not show proof of insurance. Under threat of loss of driving privileges, these people also had to reimburse the fund for any losses they caused. ${ }^{72}$

Eventually, all provinces enacted compulsory automobile insurance regimes. It is a criminal offence to own a motor vehicle that is not insured when operated on a highway. ${ }^{73}$ Special arrangements are made to provide insurance for high-risk applicants. In Ontario, for

SO 1915 , с 24 .

For the modern version, see Workplace Safety and Insurance Act, SO 1997, c 16.

Motor Vehicles Act, SO 1906, c 46, s 18.

See e.g. The Highway Traffic Amendment Act, 1930, SO 1930, c 48, s 10.

See e.g. Insurance Act, RSO 1990, c I.8, ss 239, 244. This overturned the rule enunciated by the Privy Council in Vandepitte v Preferred Accident Insurance Corp of New York, [1933] AC 70 (PC).

See e.g. Insurance Act, supra note 67, ss 118. See also s 258(4).

See e.g. ibid, s 158 (repealed SO 1999, c 12, Schedule I, s 4(17)).

See e.g. John Green, “A Fish Out of Water: Classical Fault on the Highway” (1970) 35:1 Sask L Rev 2 at 8.

Ibid.

Ibid.

See e.g. Compulsory Automobile Insurance Act, RSO 1990, c C25, s 2. 
example, insurers are required to participate in a pooling arrangement called the "Facility Association" to which brokers refer such people. ${ }^{74}$ Motorists now carry, as part of their compulsory insurance, uninsured and unidentified motorist coverage against the chance of being injured by such a person.

All this still requires claimants to identify a defendant, prove negligence, counter any allegations of contributory negligence, and establish quantum of damages. Even for successful claimants, this takes significant time and money, and it leaves some victims of accidents (those in single vehicle accidents for example) uncompensated. To address these gaps in coverage, every Canadian jurisdiction has enacted some form of no-fault insurance, either to replace or to supplement tort law and/or liability insurance. ${ }^{75}$

In British Columbia, Manitoba, Quebec, and Saskatchewan, compulsory automobile insurance is administered by government agencies created for that purpose. Private insurers, if they operate at all, are restricted to selling optional coverage additional to the compulsory package. These bodies reflect the legislative judgment that the private insurance market cannot provide necessary coverage at reasonable cost. In other words, without government involvement, the risks faced by motorists are not adequately covered at reasonable premium levels.

In other jurisdictions, compulsory coverage continues to be provided by the private market. But this coverage is subject to heavy government control. The terms of coverage are largely dictated by statute or regulation, ${ }^{76}$ or at least subject to a system of approval by regulators. ${ }^{77}$ In some provinces, premiums are subject to approval by regulators as well. ${ }^{78}$ Even where the provision of insurance is left to the private sector, insurers, as quasi-public authorities, are used as instruments of public policy.

It is pertinent to note here that significant changes in the auto insurance regime have occurred when public concern about access to and the price of insurance has put the issue on the political agenda. This occurred, for example, in the mid to late 1980 s. $^{79}$ One can foresee a similar story unfolding in response to a tightening insurance market as climate change proceeds.

\section{NATURAL DisASTER INSURANCE IN NEW ZEALAND}

In New Zealand, the risk of earthquake is significant. The country experiences a level of earthquake activity similar to California. There is a magnitude 8 earthquake about once a century, a magnitude 7 once a decade, and a magnitude 6 once a year on average. It is predicted that there is a 12 percent chance of a 7.5 magnitude earthquake occurring in the

Ibid, s 7.

See e.g. Ontario’s Insurance Act, supra note 67, s 266.

See e.g. Statutory Accident Benefits Schedule, O Reg 34/10.

See e.g. Insurance Act, supra note 67, s 227.

See e.g. Automobile Insurance Premiums Regulation, Alta Reg 124/2004; Insurance Review Board Guidelines Regulations, NS Reg 27/2007.

For an account of the history of auto insurance reform in Ontario, see Brown, "No-Fault Automobile Insurance,” supra note 21. 
area of Wellington, the capital city, within the next 30 years. ${ }^{80}$ There are also active volcanoes in New Zealand, and its climate, even before global climate change, is such that severe flooding is a regular occurrence.

The risks posed by these phenomena present challenges for the insurance industry. ${ }^{81}$ Given the uncertainties surrounding events such as these and, in particular, the potential magnitude of loss given the numbers of people likely to be affected, insurers have found it difficult to offer affordable insurance to cover them. In 1944, when the government first addressed the problem, it was estimated that, because the risks were "unascertainable," premiums for earthquake insurance were three to four times that for fire insurance. ${ }^{82}$

The government's response was to establish a commission to administer a scheme to provide compensation for earthquake loss. The concept was a state-run scheme to work in conjunction with private insurance to extend protection beyond that which could reasonably be provided by the industry alone. As stated by the Minister of Finance when introducing the bill, "[t]he endeavour has been to work out a principle under which the whole loss is deemed to be a national loss, and under which those people who might be affected will subscribe towards a fund to meet losses which may come to any of them." 83 The essentials of the scheme were as follows. People who purchased insurance on buildings from the private market were levied an additional amount to cover earthquake loss (which was invariably excluded under insurance policies themselves). This was collected by insurers and passed on to what was then called the Earthquake and War Damage Commission, which administered the fund so established. Only those who had purchased insurance were eligible. Claims were made directly to the Commission.

In 1993, the terms of coverage were redefined. ${ }^{84}$ Coverage was restricted to residential property and limited to $\$ 100,000$ for buildings and $\$ 20,000$ for contents. Despite the renaming of the agency to the "Earthquake Commission," covered perils included not only earthquake, but also natural landslip, volcanic eruption, hydrothermal activity, tsunami, flood, as well as fire caused by any of the above. ${ }^{85}$ The Commission's liability was reinsured. ${ }^{86}$ In 2010, the premium was 5 cents per $\$ 100$ of value of the insured property, up to a maximum of $\$ 67.50$ per year, ${ }^{87}$ but following the major earthquakes in Christchurch in 2010 and 2011, those numbers have been increased substantially so that the premium is now 15 cents per $\$ 100$, to a maximum of $\$ 207$ per year. ${ }^{88}$

Statistics New Zealand, New Zealand Official Year Book 2004, 104th ed (Auckland: Statistics New Zealand, 2004) at 6 [NZ Official Year Book].

Ibid at 411.

NZ, House of Representatives, Parliamentary Debates (Hansard), vol 266 (28 September 1944) at 619. Ibid.

See Earthquake Commission Act 1993 (NZ), 1993/84.

In the year ending 30 June 2003, there were 576 claims relating to earthquake damage resulting in a total value of \$980,000, and 622 landslip claims totaling \$4,796,000. NZ Official Year Book, supra note 80 at 411 .

See Simon Hartley, "\$2.5b claim on reinsurers may be option for EQC," Otago Daily Times (26 February 2011), online: Otago Daily Times <http://www.odt.co.nz/print/149356?page=0\%2C1 >.

This seems to be more than sufficient. In the year ending 30 June 2003, when claims totaled less than \$6 million, the fund's income was \$76.8 million from premiums and \$277.8 million from investments: NZ Official Year Book, supra note 80 at 411.

See "EQC Levy Increase," online: New Zealand Insurance <http://www.nzi.co.nz/AboutNZI/News-andMedia-/EQC_Levy_Increase.aspx>. 
Note that, because of the restrictions that apply (exclusion of commercial property and a limit of $\$ 100,000)$, this is not the model for a comprehensive plan. For full protection, most owners of real property need to augment the protection provided by the government scheme through private insurance. Thus, for residential property, the scheme effectively allows a homeowner to buy private insurance to which a $\$ 100,000$ deductible applies, making affordable coverage more feasible. On the other hand, to achieve the same effect, commercial property owners have to self-insure for $\$ 100,000$. For many, this may not be feasible.

In 1993, when changes were made to the New Zealand scheme, the relevance of climate change was not lost on legislators. As one Member of Parliament said:

\begin{abstract}
I think the truth is that, given some of the evidence we are now getting about global climate change and all of those other atmospheric effects, there will be more natural emergencies and natural disasters than we have in recent years. That pressure will increase rather than reduce, which will mean that New Zealand's ability to obtain reinsurance will always be difficult, and that, in turn, will mean that the pressure on our Earthquake Commission to be sharp, flexible, and able to take advantage of opportunities in a much more dynamic way than perhaps has been the case to date, will be important. ${ }^{89}$
\end{abstract}

Thus, a scheme born in other circumstances is now seen as part of an appropriate response to the insurance-related consequences of climate change.

\title{
E. British Columbia Disaster Financial Assistance Program
}

The British Columbia Disaster Financial Assistance Program is a government-sponsored insurance plan for harm to persons or property caused by natural disasters. ${ }^{90}$ There are two types of claims depending on whether the damage was caused by the government's actions to prevent or alleviate harm, or by the disaster itself. If someone's property is damaged by government action, the government is required to fully compensate that person for their loss ${ }^{91}$ without delay. ${ }^{92}$ Claims based on harm caused by the disaster itself relate to an incident that "is caused by accident, fire, explosion or technical failure or by the forces of nature [resulting] in serious harm to ... safety ... or in widespread damage to property."93

After a disaster, the government sets the criteria for eligibility for disaster financial assistance. ${ }^{94}$ Adjusters are then appointed, and applicants fill out an application form. ${ }^{95}$ The adjuster makes a recommendation for the amount of assistance. If applicants are not satisfied with the award, they can appeal. ${ }^{96}$ In order to be eligible for assistance, applicants must have taken sufficient action to protect their property. ${ }^{97}$ This could mean taking physical steps to prevent damage from the impending disaster, or holding sufficient insurance. If insurance

NZ, House of Representatives, Parliamentary Reports, vol 536 (20 July 1993) at 16579.

See "Disaster Financial Assistance Program," online: Emergency Management BC <http://www.pep. gov.bc.ca/dfa_claims/dfa.html>.

Emergency Program Act, RSBC 1996, c 111, s 19(1).

Compensation and Disaster Financial Assistance Regulation, BC Reg 124/95, ss 2-3(1) [Disaster Financial Assistance Regulation].

Emergency Program Act, supra note 91, s 1(1).

Ibid, s 20.

Disaster Financial Assistance Regulation, supra note 92, ss 19(1)-(2), 19(5).

Ibid, s 19(7).

Ibid, s 16. 
was reasonably and readily available for the damage that was suffered, the damage will not be compensated through this program. ${ }^{98}$ One specific example is that there is no assistance available for flood damage to structures in a flood plain unless they were properly protected. ${ }^{99}$

Guidelines for determining what damage is eligible for relief are laid out in the Emergency Program Act. ${ }^{100}$ In general, only repairs that are necessary to a home, livelihood, or community service organization are eligible. ${ }^{101}$ For damage to eligible personal property, the amount granted is the lesser of the cost to repair the item and the cost to replace the item with a basic model. ${ }^{102}$ For damage to structures, the amount granted is the lowest of the following: the cost to rebuild the structure, the cost to replace the structure, and the assessed value of the structure. ${ }^{103}$ Relief is limited to 80 percent of the amount over $\$ 1,000$, up to a maximum award of $\$ 300,000 .^{104}$

Where a disaster is caused by the acts or omissions of an individual or organization, the responsible party must reimburse the government for its expenditures on prevention and alleviation of the harm caused by the disaster. ${ }^{105}$ If there are multiple causes, each contributing party must pay the portion of government expenditures equal to the portion of liability attributed to them. ${ }^{106}$

In sum, the British Columbia Disaster Financial Assistance Program is essentially a government insurance plan with a 20 percent deductible. It covers only damage to property necessary for a home, livelihood, or community service organization. Individuals are expected to take all reasonable steps to protect their property, including holding private insurance.

\section{F. United States Federal EMERgency MANAgement Agency}

The United States' Federal Emergency Management Agency (FEMA) is focused on meeting the basic needs of those affected by a disaster rather than on providing insurance coverage. FEMA was created and is controlled by the Robert T. Stafford Disaster Relief and Emergency Assistance Act. ${ }^{107}$ Disaster relief is funded by the federal, state, and local governments. The share of costs borne by the federal government varies from 7 percent to 100 percent depending on the nature of the expense. ${ }^{108}$ The federal government will grant loans to state or local governments if they cannot bear their share of the financial burden.

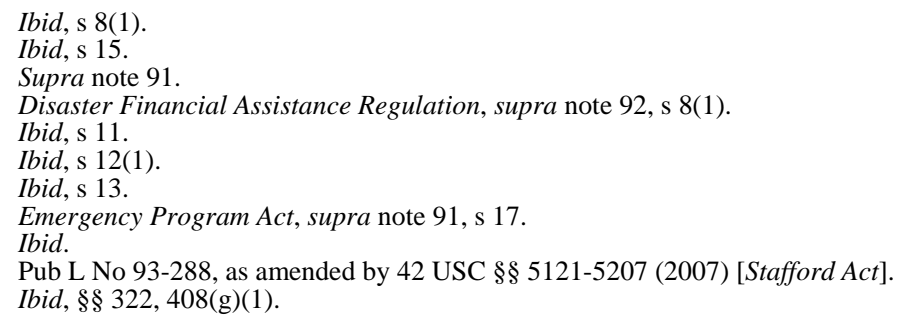


FEMA provides relief for harm caused by a major disaster. A major disaster can either be a natural disaster or a fire, flood, or explosion with any cause. ${ }^{109}$ The first priority of FEMA is to ensure the health and safety of residents affected by the disaster. To this end, necessary medicine, medical equipment, and food are provided. Other necessary measures, such as debris removal, search and rescue, emergency shelter and care, road clearance, demolition of unsafe structures, warning of further risks, and rescue and care of pets and animals are undertaken immediately following a disaster with no application procedures necessary. ${ }^{110}$ Most disaster relief money for rebuilding homes and businesses is provided in the form of loans from the Small Business Administration. ${ }^{111}$

The Individuals and Households Program (IHP) within FEMA covers necessary expenses for establishing a safe living place in the wake of a disaster. IHP does not cover business losses or losses that are covered by the individual's insurance. ${ }^{112}$ If the relevant insurance policy is insufficient, federal aid may still be granted. ${ }^{113}$ Generally, individuals are not required to have insurance in order to be eligible for aid. However, those in flood hazard areas will only get aid if they have sufficient flood insurance. If they do not have flood insurance, they may still be able to get aid for expenses that would not have been covered by the insurance anyway. ${ }^{114}$ Sometimes when an individual receives federal disaster assistance, there is a condition that they must then purchase reasonable insurance against future loss. If they fail to do so, any future claims will be denied. ${ }^{115}$ Only primary residences are eligible; IHP will not provide funding for damage to secondary or vacation homes. The maximum assistance that any individual or household can receive through the IHP is US $\$ 25,000 .^{116}$

Several types of assistance are available. The government may provide financial assistance to rent temporary housing at fair market value, or may provide free temporary housing for up to 18 months. ${ }^{117}$ IHP may cover repairs to structures to bring them to a safe and sanitary living condition, ${ }^{118}$ but will not pay extra to return the home to its pre-disaster condition. ${ }^{119}$ Eligible hazard mitigation modifications to reduce the likelihood of future damage are covered. ${ }^{120}$ Replacement or rebuilding costs may be provided, especially in rural settings where temporary housing is not available. ${ }^{121}$ Medical, dental, and funeral expenses caused by the disaster may be covered. ${ }^{122}$ Personal property, including vehicles, is also covered. ${ }^{123}$

Ibid, § 102. Natural disasters include "hurricane, tornado, storm, high water, winddriven water, tidal wave, tsunami, earthquake, volcanic eruption, landslide, mudslide, snowstorm, [and] drought” (ibid). Ibid, § 403.

FEMA, Help After a Disaster: Applicant's Guide to the Individuals \& Households Program (Washington, DC: FEMA, 2008) at 1 [FEMA Guide].

Ibid.

Ibid.

Ibid at 5.

Stafford Act, supra note 107, § 311.

Ibid, § 408(h)(1).

Ibid, § 408(c)(1).

Ibid, § 408(c)(2).

FEMA Guide, supra note 111 at 5.

Stafford Act, supra note 107, § 408(c)(2).

Ibid, § 408(c)(3).

Ibid, § 408(e)(1).

Ibid, § 408(e)(2). 
In some situations, the government can recoup some of its outlays. A person who intentionally causes a situation resulting in federal assistance must compensate the government for reasonable costs incurred in responding to the emergency. If there are multiple causes, each individual must compensate for the portion of the costs that are attributable to their intentional act or omission. ${ }^{124}$ Note that, unlike the British Columbia Disaster Financial Assistance program, only intentional acts attract the obligation to reimburse the government.

\section{INTERNATIONAL LAW, CLIMATE, AND CANADA}

Any inquiry about compensation plans necessarily involves the question of who pays. In this question, the issue of compensation is, or at least can be, connected to the issue of accountability. Ideally, the funds for compensating the harmed come from those who cause the harm. This is a basic application of corrective justice theory. But it also raises issues of deterrence. If payment can be connected to harm caused, it is possible to introduce incentives to reduce harm in exchange for reduced responsibility for payment. These principles apply in theory both under international law and under domestic law.

Thus, in thinking in a preliminary way about funding mechanisms, we can see the theoretical attraction of drawing contributions from those who contribute to the problem. If it is possible to identify those who cause or at least contribute to the problem (emitters of GHGs), they should pay. The mechanism might be subrogation by private or government insurers or direct levying, but emitters would pay. However, as we saw when discussing liability insurance, there are difficulties in establishing, let alone enforcing, tort rights. This applies not only to insured defendants in respect of liability insurance, but also in respect of first party insurers seeking to exercise subrogation rights. This problem does not necessarily apply to governments who could require, by legislation, financial contributions from emitters without proof of individual culpability for specific harm, much like workers' compensation.

Beyond that, governments have at least a theoretical source of reimbursement through international law. One reality of climate change is that its causes are not confined within national boundaries. Therefore, while it is possible to have a wholly domestic scheme to deal with compensation within the jurisdiction, it is not possible to have a causer-pays scheme within a single jurisdiction. This is where international law should, in theory, step in. If the basic principles of corrective justice were applied at the international level, then the ideal solution would be for states to contribute to an International Climate Change Compensation Fund (ICCCF) in proportion to their emissions. States whose residents suffer climate changerelated loss would then claim from that fund to help defray their costs in contributing to their domestic compensation schemes. This idea would appear consistent with the "do no harm" principle of international environmental law, according to which states have "the responsibility to ensure that activities within their jurisdiction or control do not cause damage to the environment of other States or of areas beyond the limits of national jurisdiction.”125 In a sense, it would be like a workers' compensation scheme writ large. But in reality, there

Rio Declaration on Environment and Development, 14 June 1992, 31 ILM 874, Principle 2 [Rio Declaration], reaffirmed in United Nations Conference on Sustainable Development, Rio+20: The Future We Want, UN Doc A/CONF.216/L.1 (2012) at para 15 [Rio+20]. 
are many complicating factors. In addition to the complexity of calculating which emissions should be attributed to which state ${ }^{126}$ is the problem of calculating responsibility for historic emissions. If the fund is designed on a going forward basis, then developing countries will see it as unfair, due in part to the principle of "common but differentiated responsibilities,"127 a principle of international environmental law that underpins the global climate regime. ${ }^{128}$ Yet, politically, developed countries will be reluctant to acknowledge legal responsibility for past emissions. ${ }^{129}$ An additional complication is whether contributions should be calculated to reflect per capita emissions, or total state emissions. ${ }^{130}$ As will be seen below, while the international law of state responsibility and state liability could be called upon to support the creation of an ICCCF drawing contributions from states, the current international climate law regime does not in fact reflect this understanding of state obligations. Instead, the focus at the international level has been on the mitigation of climate change, and the creation of climate adaptation funds for the least developed countries most likely to be severely impacted by climate change.

An alternate approach at the international level would be to require large industrial emitters to contribute directly to the ICCCF in proportion to their emissions. ${ }^{131}$ This would be in keeping with the polluter pays principle, ${ }^{132}$ and would be consistent with the idea of international civil liability. As will be seen below, however, while making the polluter pay is in theory a principle of international environmental law, in practice the development of international civil liability has been limited to select areas of high risk activity. Moreover, states have been notoriously slow to develop international law relating to liability and compensation for environmental harm more generally that would ensure that polluters pay, and also provide a remedy to those harmed by breaches of the "do no harm" principle. ${ }^{133}$

See David Takacs, "Forest Carbon Offsets and International Law: A Deep Equity Legal Analysis" (2010) 22:3 Geo Int'l Envtl L Rev 521 at 529-51; Fiona Harvey, “Britain merely ‘outsourcing' carbon emissions to China, says MPs," The Guardian (18 April 2012), online: The Guardian <http:// www.guardian.co.uk/environment/2012/apr/18/britain-outsourcing-carbon-emissions-china> . Rio Declaration, supra note 125, Principle 7. This Principal states that:

States shall cooperate in a spirit of global partnership to conserve, protect and restore the health and integrity of the Earth's ecosystem. In view of the different contributions to global environmental degradation, States have common but differentiated responsibilities. The developed countries acknowledge the responsibility that they bear in the international pursuit of sustainable development in view of the pressures their societies place on the global environment and of the technologies and financial resources they command.

Principle 7 was specifically reaffirmed in Rio+20, supra note 125 at para 15 .

See United Nations Framework Convention on Climate Change, 9 May 1992, 1771 UNTS 107, Article $4(2)[$ UNFCCC]. 129 See e.g. Karin Mickelson, “Leading Towards a Level Playing Field, Repaying Ecological Debt, or 43:1\&2 Osgoode Hall LJ 137; Karin Mickelson, "Beyond a Politics of the Possible? South-North Relations and Climate Justice” (2009) 10:2 Melbourne Journal of International Law 411 [Mickelson, "South-North Relations"].

130 See Mickelson, "South-North Relations," ibid at 412; Stephan Lewandowsky, "Historical Responsibilities: Carbon Emissions in Context” (1 June 2011), online: Shaping Tomorrow’s World $<$ http://www.shaping tomorrowsworld.org/lewandowskyHistorespons.html>. See e.g. Takacs, supra note 126 at 567-69.

132 Rio Declaration, supra note 125, Principle 16: "National authorities should endeavour to promote the internalization of environmental costs and the use of economic instruments, taking into account the approach that the polluter should, in principle, bear the cost of pollution, with due regard to the public interest and without distorting international trade and investment.” Reaffirmed in Rio+20, supra note 125 at para 15.

Rio Declaration, ibid, Principle 13:

States shall develop national law regarding liability and compensation for the victims of pollution and other environmental damage. States shall also cooperate in an expeditious and more determined manner to develop further international law regarding liability and compensation for adverse effects of environmental damage caused by activities within their jurisdiction or control to areas beyond their jurisdiction [emphasis added]. 
Finally, increasing attention is being given at the international level to conceptualizing climate harms as human rights violations. Thus, it is necessary to also consider how international human rights law might inform the creation and structure of an ICCCF, whether paid into by states or industrial emitters. The increasing attention being given to the human rights dimension of climate change is consistent with concerns over equity in relation to climate harms. Scholars such as Philip Cullet have argued that the international community should turn its attention to creating a liability regime to compensate those who suffer the most from climate harms. ${ }^{134}$ Cullet argues that the liability regime must be international because of the inequality inherent in the climate change problem. Most of the GHG emissions have been from wealthy northern nations, while most of the negative effects will be suffered by poor southern nations. In addition, the poorest communities within nations are both the most affected by climate changes and the least capable of adapting to them. ${ }^{135}$

But is an ICCCF feasible? The answer requires consideration of (a) public international law relating to state responsibility, state liability, and civil liability for climate harms, in terms of both international environmental and human rights dimensions, and (b) the nature of the current international climate regime and Canada's relationship to it, including contributions Canada already makes to international climate funds and the implications of Canada's recent withdrawal from the Kyoto Protocol to the United Nations Framework Convention on Climate Change. ${ }^{136}$

\section{A. RESPONSIBILITY AND LIABILITY IN INTERNATIONAL LAW}

\section{STATE RESPONSIBILITY}

Under customary international law, state responsibility is triggered when a state breaches an international legal obligation. ${ }^{137}$ In other words, for the secondary rules of state responsibility to be invoked, a state must first have engaged in wrongful conduct by breaching a primary rule of international law. Harm that results from state conduct without such a breach does not create state responsibility. ${ }^{138}$ The wrongful conduct must be attributable to the state, which creates complications where non-state actor conduct is implicated. ${ }^{139}$ Furthermore, states are only responsible for actions that were breaches of an

Reaffirmed in Rio+20, ibid at para 15.

Philippe Cullet, "Liability and Redress for Human-Induced Global Warming: Towards an International Regime” (2007) 43(A) Stan J Int'l L 99 at 102; Jutta Brunnée, “Of Sense and Sensibility: Reflections on International Liability Regimes as Tools for Environmental Protection” (2004) 53:2 ICLQ 351 at 364-67 [Brunnée, "Of Sense and Sensibility”]. See Cullet, ibid at 101-102; Mickelson, "South-North Relations," supra note 129 at 418-22. 11 December 1997, UN Doc FCCC/CP/1997/7/Add.1, 37 ILM 22 [Kyoto Protocol].

International Law Commission, Responsibility of States for Internationally Wrongful Acts, UN Doc A/56/49(Vol I)/Corr 4 (2001), Articles 1-2 [ILC, State Responsibility].

138 Wouter G Werner, "Responding to the Undesired. State Responsibility, Risk Management and Precaution" (2005) 36 Netherlands Yearbook of International Law 57 at 65; Jutta Brunnée, "International Legal Accountability Through the Lens of the Law of State Responsibility" (2005) 36 Netherlands Yearbook of International Law 21 at 29-30 [Brunnée, "International Legal Accountability”]. ILC, State Responsibility, supra note 137, Articles 4-11; Brunnée, "International Legal Accountability," ibid at 29-30. See also Sara L Seck, "Conceptualizing the Home State Duty to Protect Human Rights" in Karin Buhmann, Lynn Roseberry \& Mette Morsing, eds, Corporate Social and Human Rights Responsibilities: Global Legal and Management Perspectives (New York: Palgrave Macmillan, 2011) 25 at 39-47. 
obligation in existence at the time they occurred. ${ }^{140}$ It is unclear how this would apply in the climate change context due to the significance of historic emissions and the evolution of knowledge relating to climate harms.

Even if a state has breached an international obligation, state responsibility must first be invoked by an injured state. ${ }^{141}$ A state is considered to be injured if the obligation is owed to it individually, or to a group of states of which it is a member (obligations erga omnes partes), or to the international community as a whole (obligations erga omnes), "so long as it is specially affected by the breach or the breach radically changes the position of the states to which the obligation is owed." 142 State responsibility may also be invoked by uninjured states, with limitations on what can be claimed from the responsible state. ${ }^{143}$ If a state is found in breach of an international obligation owed to an injured state, the law of state responsibility requires that state to cease the violation, offer assurances of non-repetition, and make full reparation in the form of restitution, compensation for damage, and satisfaction. ${ }^{144}$

In theory then, the international law of state responsibility could support the creation of a fund such as the ICCCF, if the primary rules of international law support the existence of an international obligation for states to prevent climate harms and to remedy existing harms arising from climate emissions. As will be seen below, the current international climate regime itself does not in fact take this approach, although some scholars have argued that it can be interpreted to create such a primary rule. ${ }^{145}$ Moreover, as noted above, while the international environmental law principle of "do no harm" appears to support this existence of such an obligation, in practice, the "do no harm" principle is best understood as an obligation of due diligence. ${ }^{146}$

The “do no harm” principle is reflected in the ILC's 2001 Draft Articles on the Prevention of Transboundary Harm from Hazardous Activities, ${ }^{147}$ which provides in Article 3 that states should take "all appropriate measures to prevent significant transboundary harm or at any event to minimize the risk therof." 148 If this is considered a primary rule of international law, then its violation could trigger state responsibility. ${ }^{149}$ The phrase "all appropriate measures" refers to both the steps specified in the draft articles, and to the state of origin's obligation

\section{$140 \quad$ ILC, State Responsibility, ibid, Article 13.}

141 Ibid, Article 42; Brunnée, "International Legal Accountability,” supra note 138 at 30-31.

142 Brunnée, “International Legal Accountability,” ibid at 31. See also ILC, State Responsibility, ibid.

143 Brunnée, "International Legal Accountability,” ibid. ILC, State Responsibility, ibid, Articles 48, 54.

Brunnée, “International Legal Accountability,” ibid at 33; ILC, State Responsibility, ibid, Articles 30-31, 34-37. If the claiming state is non-injured, any reparation must be claimed "in the interest of the injured State or of the beneficiaries of the obligation breached,"(ILC, State Responsibility, ibid, Article 48(2)(b)).

Christina Voigt, “State Responsibility for Climate Change Damages” (2008) 77:1 Nordic J Int'l L 1 at 5-7.

John H Knox, “The Myth and Reality of Transboundary Environmental Impact Assessment” (2002) 96:2 AJIL 291 at 292, 294.

International Law Commission, Report of the International Law Commission on the work of its FiftyThird Session, UNGAOR, 56th Sess, Supp No 10, UN Doc A/56/10 (2001) at 144 [ILC, Prevention Articles]. in Retrospect” (2003) 50:3 Nethl Int'l Rev 327 at 336. See also International Law Commission, Draft Principles on the Allocation of Loss in the Case of Transboundary Harm Arising Out of Hazardous Activities in International Law Commission, Report of International Law Commission, Fifty-Eighth Session, UNGAOR, 61st Sess, Supp No 10, UN Doc A/61/10 (2006) at 118 [ILC, Loss Allocation Principles]. 
to "adopt and implement national legislation incorporating accepted international standards." ${ }^{\text {150 }}$ However, for a violation to be found, the complaining state must show a lack of due diligence on the part of the acting state. ${ }^{151}$ There is also the question of whether activities which give rise to climate harms fit within the definition of "hazardous activities" to which the Prevention Articles would apply, specifically, what threshold of GHG emissions would be considered sufficient to cause "significant" harm? Nor is it clear what would be considered "accepted international standards" in the climate context. An alternate basis upon which state responsibility for the prevention of environmental climate harms could be grounded is the precautionary principle. ${ }^{152}$ The precautionary principle could in theory support a primary rule of international law to prevent the gradual degradation of the atmosphere by requiring states to reduce emissions even in the absence of scientific certainty. ${ }^{153}$

The ILC’s 2006 Loss Allocation Principles propose a second set of primary rules that seek to compensate victims of harm by ensuring that operators are held strictly liable. ${ }^{154}$ Principle 3 provides that one of the purposes of the Loss Allocation Principles is to "ensure prompt and adequate compensation to victims of transboundary damage." ${ }^{\text {"155 }}$ Principle 4 provides that each state "should take all necessary measures to ensure that prompt and adequate compensation is available for victims of transboundary damage" which "should include the imposition of liability on the operator or, where appropriate, other person or entity" and "should not require proof of fault." "I56 If the Loss Allocation Principles reflect the primary rules of international law, ${ }^{157}$ then states that have failed to impose strict liability on GHG emitters for transboundary harms and have failed to compensate victims of transboundary harms would have breached a primary rule of international law. The difficulty would be finding a victim state to invoke state responsibility for this type of violation, given that the primary rule is designed to compensate individual victims, rather than victim states.

A similar issue arises with the law of state responsibility if climate change harms are viewed as international human rights violations, given that the rights holders are individuals

$150 \quad$ ILC, Prevention Articles, supra note 147 at 153.

151 Ibid at 153-55. See also Brunnée, “Of Sense and Sensibility,” supra note 134 at 354.

152 Werner, supra note 138 at 71. The precautionary principle is endorsed in the UNFCCC, supra note 128, Article 3(3). See also Xue Hanqin, Transboundary Damage in International Law (Cambridge: Cambridge University Press, 2003) at 224-25.

153 Werner, ibid at 73.

$154 \quad$ ILC, Loss Allocation Principles, supra note 149. Strict liability as used in international legal analysis is equivalent to absolute liability in Canadian law - that is, proof of due diligence will not serve as a defence.

155 ILC, Loss Allocation Principles, ibid, Principle 3(a) at 108.The second purpose is "to preserve and protect the environment in the event of transboundary damage, especially with regard to mitigation of damage to the environment and its restoration or reinstatement."

156 Ibid, Principle 4 at 108. Principle 4 goes beyond Article 15 of the ILC, Prevention Articles, supra note 148 , which requires states to ensure access to justice is provided in state courts for victims in accordance with the principle of non-discrimination, unless concerned states have agreed to another method of protection.

157 According to some scholars, the Loss Allocation Principles are "too cautious" if not "retrograde": AE Boyle, "Globalising Environmental Liability: The Interplay of National and International Law” (2005) 17:1 J Envtl L 3 at 19-20 (drawing upon the 2004 version of the Principles, the criticized text remained largely unchanged in 2006). But see André Nollkaemper, "Responsibility of Transnational Corporations in International Environmental Law: Three Perspectives” in Gerd Winter, ed, Multilevel Governance of Global Environmental Change: Perspectives from Science, Sociology and the Law (Cambridge: Cambridge University Press, 2006) 179 at 187-89 (endorsing the ILC focus on the state as regulators of corporate conduct). 
or groups but not states. ${ }^{158}$ Increasingly, the human rights implications of climate change have been recognized within international law. ${ }^{159}$ Moreover, the obligation of states to regulate businesses to prevent and remedy human rights violations is also recognized under international human rights law. ${ }^{160}$ Again, however, there is the technical difficulty under the law of state responsibility of finding a victim state to invoke this responsibility.

Conceptually, then, the Prevention Articles, Loss Allocation Principles, and international human rights law place the burden of preventing and compensating climate harms on states. In theory, states are under an obligation to regulate private actors to prevent harm and ensure that polluters pay compensation to victims. If these obligations are not complied with, then victim states could invoke the state responsibility of emitter states and seek a remedy including compensation. Because in the climate context many states are not complying with the above primary rules, the creation of an ICCCF would be theoretically consistent with an idea of state responsibility for breaches of international obligations. If states were in compliance, the need for an ICCCF would be limited to residual harms not captured by the regulatory and compensatory systems already implemented by states, and would amount to a regime of state liability, as will be discussed below.

The idea of state responsibility for climate harms is useful for conceptualizing compensation for climate change damage because there are many individual emitters (such as drivers of automobiles) who bear a low level of individual responsibility for climate change, and do not control the environmental policies that determine how much they emit. ${ }^{161}$ It is more practical to make the state responsible for failing to institute effective environmental policies than to try to hold each individual private emitter liable. ${ }^{162}$

In practice, however, state responsibility is not (yet) effective at compensating climate change damage. Aside from questions relating to the invocation of state responsibility, ${ }^{163}$ one of the main problems that plagues climate change litigation, as noted earlier, is proof of causation. ${ }^{164}$ With scientific uncertainty, many emitters, and many other natural factors, it is

Brunnée, “International Legal Accountability,” supra note 138 at 42 (noting that "the main impediments to this mode of accountability for human rights violations are the uncertainties as to which rights have peremptory character and erga omnes effect.... [A]bsent primary norms that have these special characteristics, or treaty rules that create obligations erga omnes partes, the circumstances in which states can hold one another accountable for human rights violations are limited”).

See Report of the Office of the United Nations High Commissioner for Human Rights on the Relationship Between Climate Change and Human Rights, UN Doc A/HRC/10/61, online: United Nations, Office of the High Commissioner for Human Rights <http://www.ohchr.org/EN/Issues/ HRAndclimateChange/Pages/Sturdy.aspx>; John H Knox, "Linking Human Rights and Climate Change at the United Nations” (2009) 33:2 Harv Envtl L Rev 477; Svitlana Kravchenko, "Right to Carbon or Right to Life: Human Rights Approaches to Climate Change” (2008) 9:3 Vermont Journal of Environmental Law 513.

160 See Guiding Principles on Business and Human Rights: Implementing the United Nations "Protect, Respect and Remedy” Framework, UN Doc A/HRC/17/31 (2011) [UN, Guiding Principles]; Sara L Seck, "Collective Responsibility and Transnational Corporate Conduct" in Tracy Isaacs \& Richard Vernon, eds, Accountability for Collective Wrongdoing (Cambridge: Cambridge University Press, 2011) 140 at $149-57$.

$161 \quad$ Cullet, supra note 134 at 108.

162 Ibid. From an equity perspective, Cullet also notes that as citizens of developing nations would not be able to effectively sue large emitters in developed nations, they would be better off if their government could represent them.

163 See ibid. See also Andrew Strauss, "Climate Change Litigation: Opening the Door to the International Court of Justice” in Burns \& Osofsky, supra note 11, 334.

164 Prue Taylor, An Ecological Approach to International Law: Responding to Challenges of Climate Change (New York: Routledge, 1998) at 108. 
extremely difficult to prove direct causation between a country's high GHG emissions and a specific harm suffered. Because historic emissions are likely not compensable under state responsibility, even if the amount of climate change caused by those emissions is sufficient to cause the harm, the complaining state will not be compensated. In addition, like most international law, state responsibility is anthropocentric. Harm to humans and property can be compensated, but it is much more difficult to provide compensation for non-economic harm to the environment. ${ }^{165}$

\section{2. $\quad$ STATE LIABILITY AND CIVIL LIABILITY}

Two alternate approaches to the compensation of climate harms under international law are state liability and civil liability. While state responsibility requires a state to engage in internationally wrongful conduct before being required to compensate for harms, state liability is designed to capture those situations where a state has harmed another state, yet has not engaged in wrongful conduct. As the primary rule obligations described above often require states to act with due diligence to prevent significant harms, gaps in coverage arise where a harm nevertheless ensues despite a state having met its due diligence obligation or where the threshold of harm caused by an individual state does not meet that of significant harm, which is a potential issue in the climate context. ${ }^{166}$ State liability is essentially strict liability for state actions, and while not often invoked, may be considered a subsidiary liability that could compensate harms not covered by state responsibility or international civil liability. ${ }^{167}$

Strict state liability could be very beneficial for a climate change compensation system. It is designed to protect innocent victims of a foreign nation's decisions from being forced to bear the risks of those decisions. ${ }^{168}$ Individuals rely on their government to be the insurer of last resort against natural disasters, which will be the main type of damage suffered due to climate change. ${ }^{169}$ They would be represented by their government against the government of the emitting states, and then compensated by their government. Yet while the appeal to strict state liability is obvious, it has rarely been used in international law; the exceptions being to compensate for damage caused by space objects and damage to Antarctica, ${ }^{170}$ as well as to compensate victims of harm caused by Iraq's invasion of Kuwait. ${ }^{171}$

State liability is a popular theoretical approach to compensation of environmental harms. It would provide better protection for the most vulnerable populations in the world and would

Ibid at 118. See generally Michael Bowman \& Alan Boyle, eds, Environmental Damage in International and Comparative Law: Problems of Definition and Valuation (Oxford: Oxford University Press, 2002). Günther Handl, “International Accountability for Transboundary Environmental Harm Revisited: What Role for ‘State Liability’?” (2007) 37:2-3 Envtl Pol’y \& L 116 at 118; Hanqin, supra note 152 at 136. Hanqin, ibid at 300; Handl, ibid at 121.

Taylor, supra note 164 at 150.

Handl, supra note 166 at 122.

Alexandre Kiss \& Dinah Shelton, "Strict Liability in International Environmental Law" in Tafsir Malick Ndiaye \& Rüdiger Wolfrum, eds, Law of the Sea, Environmental Law and Settlement of Disputes: Liber Amicorum Judge Thomas A Mensah (Boston: Martinus Nijhoff, 2007) at 1136-37.

Horbach \& Bekker, supra note 149 at 362 . As a condition of the ceasefire, Iraq had to accept liability under international law for direct loss and damage as a result of their invasion and occupation of Kuwait. See Condition 16 in UN Security Council, Resolution 687, S/RES/687 (1991); UN Compensation Commission "Introduction," online: UN Compensation Commission <http://www.uncc.ch/introduc. htm>. 
force the countries that most benefit from polluting behavior to pay the true cost. Despite the appeal, there are many practical difficulties to instituting and using a state liability regime. First of all, it is difficult to apportion responsibility when several states have contributed to the harm. ${ }^{172}$ Joint and several liability would be complex, as it would require the injured state to make a complaint of every emitting state. A potentially devastating setback is that claims can only be brought against states that have agreed to participate in the regime. ${ }^{173}$ The idea of even residual state liability is rejected by many states. ${ }^{174}$ Indeed, it is this political reality that led the ILC to focus on the allocation of loss to private actors rather than continuing with the project of state liability as initially proposed. ${ }^{175}$ As discussed above, the Loss Allocation Principles support states imposing strict liability on private actors, but do not support imposing strict liability on states unless they are themselves the operator of the project. ${ }^{176}$

An alternate approach is that of international civil liability. Similar to domestic tort law, international civil liability would ensure that private actors are held liable for damage caused by their activities and must pay reparation to the victims. In the climate change context, such a regime would be based on strict liability for emissions.

International liability agreements have several common traits. Liability is generally strict, with a defined set of exceptions. ${ }^{177}$ Liability is limited both in monetary amount and in time. ${ }^{178}$ Mandatory insurance is often stipulated, and in some cases so are supplementary compensation funds. ${ }^{179}$ Although harm to the environment is taken into account when determining damages, there is no economic compensation for irreversible non-economic damage to the environment. ${ }^{180}$ Such civil liability regimes are politically unpopular, however, and the only ones currently in force are for nuclear and oil pollution. ${ }^{181}$ The suddenness of nuclear accidents and oil spills is very different from the gradual degradation caused by GHG emissions. Moreover, instituting an international civil liability regime for climate change damage would be politically challenging. ${ }^{182}$ Without comprehensive coverage, the regime might not only fail but also harm the states that agree to it, as their large emitters flee to other nations to escape liability. If climate harms were viewed as human rights violations, a conceptually parallel idea would be for businesses to hold direct obligations under international human rights law, including obligations to respect the rights of those who could be impacted by climate harms. The recent Guiding Principles on business and human rights

\footnotetext{
172 Phoebe Okowa, “The Legacy of Trail Smelter in the Field of Transboundary Air Pollution” in Rebecca M Bratspies \& Russell A Miller, eds, Transboundary Harm in International Law: Lessons from the Trail Smelter Arbitration (Cambridge: Cambridge University Press, 2006) 195 at 202.

Ibid at 203.

Handl, supra note 166 at 121.

Brunnée, “Of Sense and Sensibility,” supra note 134 at 355. See ILC, Loss Allocation Principles, supra note 149.

Kiss \& Shelton, supra note 170 at 1139.

Ibid at 1150 .

Ibid at 1150; Cullet, supra note 134 at 113; Brunnée, “Of Sense and Sensibility,” supra note 134 at 364. Brunnée, "Of Sense and Sensibility," ibid at 364.

Ibid; Cullet, supra note 134 at 113.

Brunnée, “Of Sense and Sensibility,” ibid at 365. See also Anne Daniel, "Civil Liability Regimes as a Complement to Multilateral Environmental Agreements: Sound International Policy or False Comfort?” (2003) 12:3 RECIEL 225 at 226.

182 Russell A Miller, "Surprising Parallels between Trail Smelter and the Global Climate Change Regime" in Bratspies \& Miller, supra note 172, 167 at 173.
} 
do recognize the corporate responsibility to respect rights, although not as a legal obligation under international law. ${ }^{183}$

International civil liability is arguably the most intuitively satisfying solution to climate change compensation, despite the complexity of identifying sources of anthropogenic climate change. According to the polluter pays principle, all the costs of pollution, including compensation to victims, should be borne by the polluting entity ${ }^{184}$ As private emitters have caused much of the damage to the atmosphere, it follows that they should bear the burden of the consequences. ${ }^{185}$ Following the polluter pays principle would force private emitters to internalize the true costs of their behavior, which should theoretically force them to behave more efficiently and provide strong incentives for decreasing emissions. ${ }^{186}$ However, incentives will only be correctly aligned if polluters have to pay for almost all the damage caused by their emissions, which is not the case in most environmental liability regimes because of the investment and skill needed to bring a complaint. ${ }^{187}$ International civil liability could also provide a good backup system for when state responsibility fails to compensate victims, especially if it were based on strict liability. ${ }^{188}$ Notably, Principle 7 of the Loss Allocation Principles specifically encourages states to conclude "specific global, regional or bilateral agreements” in respect of particular categories of hazardous activities, including within them arrangements for industry and state funds to provide supplementary compensation. ${ }^{189}$ However, as will be seen below, no conceptually comparable funds have been created in the climate context.

The idea of international civil liability accords with an ICCCF into which polluting companies are required to pay. Yet, while theoretically interesting, there are few existing models, and in the climate context such an arrangement appears politically impossible.

\section{B. CANADA AND THE INTERNATIONAL ClimATE REgIME}

Under current international law, 195 states, including Canada and all major GHG emitter states, are parties to the UNFCCC, ${ }^{190}$ which came into force in $1994 .{ }^{191}$ The UNFCCC and related agreements such as the Kyoto Protocol are designed with the primary goals of cutting greenhouse gas emissions, and funding climate change adaptation in developing countries. State parties to the UNFCCC have committed themselves to contributing to several climate related funds. However, these funds are conceptually different from an ICCCF due to the focus on mitigation and adaptation rather than compensation for climate harms. Interestingly,

UN, Guiding Principles, supra note 160, Principles 11-24. The responsibility to respect requires companies to exercise due diligence to prevent human rights violations, and includes corporate responsibility to provide a remedy for human rights violations. See generally Radu Mares, ed, The UN Guiding Principles on Business and Human Rights: Foundations and Implementation (Boston: Martinus Nijhoff, 2012).

Horbach \& Bekker, supra note 149 at 339.

Cullet, supra note 134 at 100.

Brunnée, “Of Sense and Sensibility," supra note 134 at 365. However, this has not been reflected in some studies of strict liability regimes in Europe (ibid at 366).

Ibid at 367.

Ibid at 365.

ILC, Loss Allocation Principles, supra note 149, Principle 7 at 180.

Supra note 128.

Canada became a signatory to the UNFCCC in 1992 at the Rio conference, and ratified it in December of the same year. 
while an international insurance pool was proposed by the Alliance of Small Island States in 1991, this was rejected. ${ }^{192}$

\section{UNITED NATIONS FRAMEWORK CONVENTION ON CLIMATE CHANGE}

The basic objective of the UNFCCC according to Article 2 is "not to reverse greenhouse gas emissions but to stabilize them 'at a level that would prevent dangerous anthropogenic interference with the climate system." "'193 Article 3 of the UNFCCC incorporates several principles from the Rio Declaration, including endorsements of equity and "common but differentiated responsibility," the principle of intergenerational equity, and the precautionary approach. The distinction between developed and developing states forms an integral part of the UNFCCC, ${ }^{194}$ with developed nations and economies in transition (Annex I parties) agreeing to undertake specific emissions goals and commitments, while developing nations undertake to mitigate climate change without specific targets. ${ }^{195}$ All parties must report on their efforts, subject to capacity. ${ }^{196}$ In addition, developed countries (Annex II parties) commit to providing financial resources and technology transfer to developing country parties in order to enable them to meet their reporting and mitigation commitments under the UNFCCC. ${ }^{197}$ Developed countries also commit to assisting developing countries that are particularly vulnerable to the adverse effects of climate change to cover the costs of adaptation. ${ }^{198}$ Article 11 of the UNFCCC creates a financial mechanism, which was entrusted on an interim basis to the Global Environmental Facility (GEF). ${ }^{199}$

Farhana Yamin \& Joanna Depledge, The International Climate Change Regime: A Guide to Rules, Institutions and Procedures (Cambridge: Cambridge University Press, 2004) at 227. According to Bodansky, while this proposal was not adopted, it led to the inclusion of Article 4(4) of the UNFCCC, which provides that developed countries will assist vulnerable developing countries with the costs of climate change adaptation. See Daniel Bodansky, "The United Nations Framework Convention on Climate Change: A Commentary” (1993) 18:2 Yale J Int’l L 451 at 528. David Freestone, "The International Climate Change Legal and Institutional Framework: An Overview" in David Freestone \& Charlotte Streck, eds, Legal Aspects of Carbon Trading: Kyoto, Copenhagen, and Beyond (Oxford: Oxford University Press, 2009) 3 at 5, citing UNFCCC, supra note 128, Article 2. Annex I lists developed countries and countries with economies in transition; Annex II lists developed countries only. Non-Annex countries are developing countries.

UNFCCC, supra note 128, Article 4(2). According to Voigt, supra note 145 at 6, one interpretation of Article 4(2) and Article 2 of the UNFCCC could oblige "parties to take action to adopt policies and measures to secure the stabilization of atmospheric concentrations of greenhouse gases. These Articles together could, therefore, be understood as a primary rule that when breached establishes a wrongful act," thus triggering a state responsibility. This, however, is only one interpretation. UNFCCC, ibid, Article 12.

Ibid, Article 4(3), (5), (7).

Ibid, Article 4(4). See also ibid, Article 4(8).

Ibid, Article 21(3). See Freestone, supra note 193 at 5-7. See also "What is the GEF," online: GEF <http://www.thegef.org/gef/whatisgef>. The GEF was set up by the UN Environment Program, the UN Development Program, and the World Bank in 1991. It funds not only climate change but also ozone depletion, international waters, biodiversity conservation, desertification and deforestation, and persistent organic pollutants. The fund was replenished four times between 1994 and 2006. See Freestone, supra note 193 at 23-25. See further David Freestone, “The Establishment, Role and Evolution of the Global Environmental Facility: Operationalising Common But Differentiated Responsibility?” in Ndiaye \& Wolfrum, supra note 170 at 1077. 


\section{KYOTO PROTOCOL}

The Kyoto Protocol sets legally binding emission reduction targets to reduce GHGs of developed country parties for a commitment period of 2008-2012. ${ }^{200}$ The Kyoto Protocol was adopted at the third session of the Conference of the Parties in Kyoto, Japan in 1997, and entered into force in 2005, after ratification by the Russian Federation, an Annex I party. ${ }^{201}$ Among the notable features of the Kyoto Protocol are flexibility mechanisms to facilitate the meeting of targets. These include emissions trading, ${ }^{202}$ joint implementation by developed countries, ${ }^{203}$ and the clean development mechanism, ${ }^{204}$ which permits private or public parties from developed countries to work with developing countries to undertake projects for which certified emission reductions units are awarded. ${ }^{205}$ The Kyoto Protocol created two financial mechanisms, the first aimed at further assisting the least developed countries to fund the costs of adaptation, ${ }^{206}$ while the second further committed developed country parties to support an adaptation fund for developing countries. ${ }^{207}$

Canada signed the Kyoto Protocol on 29 April 1998, and ratified it on 17 December 2002. ${ }^{208}$ As noted above, the Kyoto Protocol came into force for all state parties in 2005. Yet, while Canada ratified the Protocol, there was no real plan for effective implementation. In response, the House of Commons passed a private member's bill called the Kyoto Protocol Implementation $\mathrm{Act}^{209}$ which mandated the Minster of the Environment to create a yearly Climate Change Plan that would describe the "measures to be taken to ensure that Canada meets its obligations" ${ }^{210}$ under the Kyoto Protocol. A Climate Change Plan was adopted, ${ }^{211}$ but its adequacy was challenged in a judicial review application brought on behalf of Friends of the Earth Canada, who claimed that the content of the Climate Change Plan was not sufficient for Canada to be in compliance with its Kyoto Protocol obligations. ${ }^{212}$ This judicial review failed on the basis that while the failure to prepare a plan might be justiciable, an evaluation of its content was not. ${ }^{213}$

Kyoto Protocol, supra note 136, Article 2 (referring to Annex 1 parties to UNFCCC), Article 3(1) (committing to GHG emission reductions of at least 5 percent below 1990 levels in the commitment period of 2008 to 2012). Emissions goals could be met by the creation of sinks through certain types of land use, land use change, and forestry, including afforestation and reforestation. See Yamin \& Depledge, supra note 192 at 119-21.

201 Freestone, supra note 193 at 18-19.

202 Kyoto Protocol, supra note 136, Article 17. See Freestone, ibid at 16-17.

203 Kyoto Protocol, ibid, Article 6. See Freestone, ibid at 13-14.

204 Kyoto Protocol, ibid, Article 12. See Freestone, ibid at 14-16.

205 Kyoto Protocol, ibid. See generally Yamin \& Depledge, supra note 192 at 146-95.

$206 \quad$ Kyoto Protocol, ibid, Article 12(8).

207 Ibid, Article 11(2)(a).

See "Status of Ratification of the Kyoto Protocol," online: United Nations Framework Convention on Climate Change <http://unfccc.int/kyoto_protocol/status_of_ratification/items/2613.php> [Kyoto Ratification].

SC 2007, c 30 [KPIA]. See Robert Dufresne, Kyoto Protocol Implementation Act: Implementation and Consequences (27 November 2007), PRB 07-40E, online: Parliament of Canada <http://www.parl.gc.ca/ Content/LOP/ResearchPublications/prb0740-e.pdf $>$ at 4.

210 KPIA, ibid, s 5(1)(a).

211 Environment Canada, A Climate Change Plan for the Purposes of the Kyoto Protocol Implementation Act - 2007 (Ottawa: Environment Canada, 2007), online: Environment Canada <http://www.ec.gc.ca/ doc/ed-es/p_123/s4_eng.htm>.

212 Friends of the Earth - Les Ami(e)s de la Terre v Canada (Governor in Council), 2008 FC 1183, [2009] 3 FCR 201 [Friends (FC)], aff'd 2009 FCA 297, 313 DLR (4th) 767 [Friends (FCA)].

213 Friends (FC), ibid at para 34; aff'd in Friends (FCA), ibid at para 1. Occurring simultaneously as the litigation, Stéphane Dion, MP of the Liberal Party introduced the idea of a Federal Carbon Tax: see Daniel Rosenblum, "Dion: 'Make Polluters Pay and Put Every Single Penny Back into the Hands of Canadians, "’ Carbon Tax Center (20 June 2008), online: Carbon Tax Center < http://www.carbontax.org/ 
Despite this, on 12 December $2011^{214}$ the Minister of the Environment announced Canada's intent to formally withdraw from the Kyoto Protocol, arguing that for Canada to meet the Kyoto targets, it would have to spend \$14 billion to buy carbon credits. Moreover, Canada took the position that it would not meet its GHG reduction commitments unless key GHG contributors from the developing world had committed to binding targets as well. ${ }^{215}$ This withdrawal has not gone unchallenged, as former MP Daniel Turp filed a motion to the Federal Court to challenge the legality of Canada's withdrawal. ${ }^{216}$ However, the application for judicial review was rejected by the Federal Court in July 2012. ${ }^{217}$

\section{Bali, COPENHAgen, CANCUn, AND DURBAN}

There have been several attempts to negotiate further developments in the climate regime. The 2007 Bali Climate Change Conference led to the adoption of the Bali Roadmap. ${ }^{218}$ The 2009 Conference of the Parties resulted in the Copenhagen Accord, ${ }^{219}$ in which developed and developing countries, including the United States and China, agreed aspirationally to the need to limit warming to $2^{\circ} \mathrm{C}$ on a global level. ${ }^{220} \mathrm{In}$ addition to differing degrees of commitment to climate change mitigation on the part of developed and developing country parties, the Copenhagen Accord identified new funding commitments. ${ }^{221}$ These included a collective commitment by developed countries of $\$ 30$ billion in "new and additional" resources in 2010-2012 to help developing countries reduce emissions, preserve forests, and adapt to climate change, as well as a goal of mobilizing $\$ 100$ billion a year in public and private finance by 2020 to address the needs of developing countries. ${ }^{222}$

blogarchives/2008/06/20/dion-\%E2\%80\%9Cmake-polluters-pay-and-put-every-single-penny-back-intothe-hands-of-canadians\%E2\%80\%9D/>; Liberal Party of Canada, The Green Shift: Building a Canadian Economy for the 21st Century (Ottawa: Liberal Party of Canada, 2008), online: University of Laval <http://www.poltext.capp.ulaval.ca/upload/ca 2008lib_plt_eng._05012009_111617.pdf> [The Green Shift].

The announcement and official intent to withdraw came days after the Durban Conference for the seventeenth Conference of the Parties.

Campbell Clark, “China and India lead condemnation of Canada’s Kyoto withdrawal,” The Globe and Mail (13 December 2011), online: The Globe and Mail <http://www.theglobeandmail.com/news/ politics/china-and-india-lead-condemnation-of-canadas-kyoto-withdrawal/article2270216>.

"Ex-Bloc MP takes Tories to court for ditching Kyoto climate deal,” The Globe and Mail (13 January 2012), online: The Globe and Mail <http://www.theglobeandmail.com/news/politics/ex-bloc-mp-takestories-to-court-for-ditching-kyoto-climate-deal/article2302120/>.

Turp v Canada (Minister of Justice), 2012 FC 893, [2012] FCJ no 944 (QL). Specifically, Justice Simon Noël concluded: "the KPIA contains no provision, condition or restriction that would limit the royal prerogative of the government to withdraw from the Protocol” (ibid at para 25). This decision will likely be appealed (see "Protocole de Kyoto: L’ÉQUIPE KYOTO porte en appel le jugement de la cour fédérale” (17 July 2012), online: AQLPA < http://www.aqlpa.com/actualites/communiques/458-lequipekyoto-porte-en-appel-le-jugement-de-la-cour-federale.html $>$ ).

"Now, up to and beyond 2012: The Bali Road Map,” online: United Nations Framework Convention on Climate Change <http://unfccc.int/essential_background/bali_road_map/items/6072.php> .

18 December 2009, in United Nations Framework Convention on Climate Change (UNFCCC), Report of the Conference of Parties on its Fiftieth Session, Held in Copenhagen from 7 to 19 December 2009 (30 March 2010), online: UNFCCC <http://unfccc.int/resource/docs/2009/cop15/eng/11a01.pdf> [Copenhagen Accord].

Ibid at 5. The Accord states in part: "We emphasise our strong political will to urgently combat climate change in accordance with the principle of common but differentiated responsibilities and respective capabilities" (ibid at 5). See also Elliot Diringer, Fifteenth Session of the Conference of the Parties to the United Nations Framework Convention on Climate Change and Fifth Session of the Meeting of the Parties to the Kyoto Protocol (Copenhagen: Center for Climate and Energy Solutions, 2009), online: PEW Center on Global Climate Change $<$ http://www.pewclimate.org/ international/copenhagen-climatesummit-summary>; “Copenhagen Accord,” online: UNFCCC < http://unfccc.int/meetings/copenhagen_ dec_2009/items/5262.php>.

Copenhagen Accord, ibid at 6.

Ibid. The Accord speaks of the Copenhagen Green Climate Fund through which much of the funding should flow. 
In 2010, the parties met in Cancun, Mexico. Building upon the meeting in Copenhagen, developed countries agreed to reduce emissions in alignment with a $2{ }^{\circ} \mathrm{C}$ increase, relying on a quantified economy-wide emission reduction target, and a registry was created for actions of developing countries in reducing emissions. ${ }^{223}$ Furthermore, three specific institutions were created to coordinate international action to adapt and mitigate the impacts of climate change: (1) a Green Climate Fund ${ }^{224}$ for the deployment and accountability of funds for developing countries, (2) a Technology Mechanism ${ }^{225}$ to ensure clean technologies arrive in a timely manner where needed, and (3) an Adaptation Framework ${ }^{226}$ to increase international co-operation to assist developing countries in protecting themselves from the impacts of climate change. Additionally, the Cancun Agreements "[encourage] all Parties to find effective ways to reduce the human pressure on forests that results in greenhouse gas emissions, including actions to address drivers of deforestation."227

At the December 2011 meeting of the parties to the UNFCCC in Durban, South Africa, an agreement was reached to negotiate a legally binding treaty for the reduction of emissions in both developed and developing nations by 2015. In particular, Article 4 of Decision 1 states that:

[T] ]he Ad Hoc Working Group on the Durban Platform for Enhanced Action shall complete its work as early as possible but no later than 2015 in order to adopt this protocol, another legal instrument or an agreed outcome with legal force at the twenty-first session of the Conference of the Parties and for it to come into effect and be implemented from $2020 .^{228}$

Notably, the latest meeting in Doha, Qatar in 2012 (the eighteenth Conference of the Parties) adopted a decision that specifically explored "approaches to address loss and damage associated with climate change impacts in developing countries."229

Report of the Conference of the Parties on its Sixteenth Session, Held in Cancun from 29 November to 19 December 2010 (15 March 2011), online: UNFCCC <http://unfccc.int/resource/docs/2010/cop16/ eng/07a01.pdf> [Cancun Agreements]. See also "What Governments will do in 2011," online: UNFCCC: Cancun Agreements <http://cancun.unfccc.int/what-governments-will-do-in-2011/>. "Green Climate Fund," online: UNFCCC <http://unfccc.int/cooperation_and_support/financial_ mechanism/green_climate_fund/items/5869.php>; James Murray, "Cancun Ğreen Fund to dominate global climate finance,” Business Green (13 December 2010), online: Business Green <http://www. businessgreen.com/bg/news/1931989/cancun-green-fund-dominate-global-climate-finance>. “Technology Transfer Clearinghouse,” online: UNFCCC <http://unfccc.int/ttclear/jsp/index.jsp>.

226 “Cancun Adaptation Framework,” online: UNFCCC < http://unfccc.int/adaptation/cancun_adaptation_ framework/items/5852.php>.

227 Cancun Agreements, supra note 223 at 12 [emphasis omitted]. See Takacs, supra note 126 at 529-36 for a detailed discussion of deforestation, greenhouse gas emissions, and the international climate change regime.

228 Report of the Conference of the Parties on its Seventeenth Session, Held in Durban from 28 November to 11 December 2011 (15 March 2012), online: UNFCCC <http://unfccc.int/resource/docs/2011/ cop17/eng/09a01.pdf > at 2 [Durban Platform] [emphasis added]. See also Fiona Harvey \& John Vidal, "Global climate change treaty in sight after Durban breakthrough,” The Guardian (11 December 2011), online: The Guardian <http://www.guardian.co.uk/environment/2011/dec/11/global-climate-changetreaty-durban>.

229 UNFCCC, Approaches to address loss and damage associated with climate change impacts in developing countries that are particularly vulnerable to the adverse effects of climate change to enhance adaptive capacity (Draft), 18th Sess, COP, online: UNFCCC < http://unfccc.int/files/meetings/doha_ nov_2012/decisions/applications/pdf/cmp_lossanddamage.pdf $>$. 


\section{CONCLUSIONS: Climate Funds AND CANADA}

As can be seen from the above overview, a key element of the climate regime is the need for developed countries to fund adaptation and mitigation efforts by developing countries, in particular those most vulnerable to climate harms. Specific funds were set up over the years, ${ }^{230}$ and Canada has contributed or pledged contributions to many. For example, the Special Climate Change Fund, ${ }^{231}$ the Least Developed Countries Fund, ${ }^{232}$ and the Adaptation Fund $^{233}$ were all set in 2001 at the seventh session of the Conference of the Parties in Marrakech. Canada has contributed to various climate funds over the year. ${ }^{234}$ However, the entire climate regime is designed around the need to fund adaptation and mitigation efforts by poorer countries, not around ideas of corrective justice or deterrence, or even implementation of the polluter pays principle. Accordingly, despite various funding mechanisms, there is no existing model within the global climate regime that reflects the compensation function of the proposed ICCCF.

\section{CONCLUSIONS}

The current international climate change regime is focused on mitigation and adaptation, and does not mirror the principles of corrective justice, deterrence, or polluter pays that are implicit within the structure of insurance law. While some scholars have argued for the need for a liability regime to protect the populations most vulnerable to climate change, ${ }^{235}$ the reality is that even if such a regime were implemented on a global scale, developed countries like Canada, which are high emitters and the least vulnerable, would be paying into such a regime, not receiving compensation from it. ${ }^{236}$ Accordingly, even if an ICCCF were

See Annamaria La Chimia, "Climate Change and Aid Funding: An Appraisal of Recent Developments" in Stephen Farrall, Tawhida Ahmed \& Duncan French, eds, Criminological and Legal Consequences of Climate Change (Portland: Hart, 2012) at 142-45; MJ Mace, "Funding for Adaptation to Climate Change: UNFCCC and GEF Developments since COP-7" (2005) 14:3 RECIEL 225.

"Special Climate Change Fund," online: Climate Funds Update < http://www.climatefundsupdate.org/ listing/special-climate-change-fund>.

“Least Developed Countries Fund," online: Climate Funds Update <http://www.climatefundsupdate.org/ listing/least-developed-countries-fund $>$.

"Adaptation Fund," online: Climate Funds Update <http://www.climatefundsupdate.org/listing/ adaptation-fund>; see also “Adaptation,” online: UNFCCC <http://unfccc.int/adaptation/items/4159. php>.

See Guy Saint-Jacques, “Canada's Climate Change Mitigation Plan” (17 May 2012), online: Government of Canada <http://unfccc.int/files/bodies/awg-lca/application/pdf/20120517_canada_1749. pdf> at 30; Government of Canada, "Canada’s Fast-Start Financing: Progress Report” (May 2012), online: UNFCCC $<$ http://unfccc.int/files/adaptation/application/pdf/fast_start_finance_progress_report_ canada_-_final.pdf>; "Fast-Start Financing: Multi-Sector Initiatives," online: Canada's Action on Climate Change <http://www.climate change.gc.ca/ default.asp?lang=En\&n=1A68CB1C-1>. Also, Canada pledged \$1.2 billion in climate change financing to developing nations from 2010 to 2013 (see "Backgrounder: The Canadian Climate Change Fund at the World Bank’s International Finance Corporation," online: Environment Canada <http://www.ec.gc.ca/default.asp?lang=En\&n=56D4043B$1 \&$ news=80B8FC54-AC0E-498E-8D2A-FF13C27E426C >). Canada has also created specific funds under this \$1.2 billion (see Jenny Lei Ravelo, “Canada Commits \$253M to New Climate Fund,” Devex News (1 May 2012), online: The Development Newswire <http://www.devex.com/en/news/blogs/ canada-commits-253m-to-new-climate-fund >; Jenny Lei Ravelo, "Wanted: Proposals for \$20M Canada Fund" Devex News (14 February 2012), online: The Development Newswire <http://www.devex.com/ en/news/blogs/wanted-proposals-for-20m-canada-fund>).

Cullet, supra note 134 at $115-16$.

Ibid at 117-19; "The Vanishing North," supra note 13. This is not to suggest that certain groups within Canada may not be among the most vulnerable, such as notably the Inuit. See Sheila Watt-Cloutier, "Petition to the Inter American Commission on Human Rights Seeking Relief from Violations Resulting from Global Warming Caused by Acts and Omissions of the United States," (7 December 2005), online: Inuit Circumpolar Council <http://www.inuitcircumpolar.com/files/uploads/icc-files/FINALPetition ICC.pdf>. 
politically feasible, which appears highly unlikely, any such fund would not be likely to provide a source of funding for a Canadian climate insurance mechanism. Therefore, the solution to the problems facing Canadian climate insurers and ordinary Canadians must, as a result, come from within Canada itself.

While it is beyond the scope of this article to seriously canvass internal solutions to the climate insurance problem, some ideas will be tentatively proposed here. One idea is that Canada could implement a carbon tax, with the funds collected used to support a climate compensation insurance fund. While numerous jurisdictions have implemented carbon taxes already, including Quebec and British Columbia, ${ }^{237}$ it does not appear that funds collected from a carbon tax have been used for such an insurance purpose. For example, climate tax funds have been used to support carbon mitigation programs, ${ }^{238}$ income tax reductions to individuals, ${ }^{239}$ and the supplementation of government budgets, ${ }^{240}$ but not for compensating climate-related damage. In Canada, the idea of a federal carbon tax has not been well received by Canadians in previous federal elections. ${ }^{241}$ It is noteworthy that various jurisdictions have implemented drought and flood taxes to raise money for natural disaster funds, ${ }^{242}$ but none have specifically adopted a carbon tax for this purpose.

Yet the idea has interesting possibilities. A carbon tax could fund a disaster relief scheme to replace or supplement private insurance. The scheme could be modeled on that in place in British Columbia, or in New Zealand. Or it could be in the nature of workers' compensation in the sense that funding would be drawn proportionately from all identified emitters without connecting any single emitter to any single claimant. Because some climate change causing emissions come from other countries, this would not be a complete causerpay scheme; however, it would still go some way to reflecting corrective justice and would impose incentives to reduce emissions. Clearly the details of obligations to contribute and entitlements to claim would require considerable attention, but unless people are to be left to self-insure risks that cannot be covered by the private insurance market, government involvement, in some form, is the only solution.

Some climate-related risks will continue to be covered by private insurance. Accordingly, an additional idea would be to ensure that insurers themselves play a role through the implementation of best practices for themselves and their clients. These include: (1) maintaining insurance for extreme weather events; (2) improving modeling by incorporating

See Jenny Sumner, Lori Bird \& Hillary Smith, Carbon Taxes: A Review of Experience and Policy Design Considerations, (Golden, CO: National Renewable Energy Laboratory, 2009); Marc Lee \& Toby Sanger, Is BC's Carbon Tax Fair? An Impact Analysis for Different Income Levels (Vancouver: Canadian Centre for Policy Alternatives, 2008).

238 Sumner, Bird \& Smith, ibid at iv. Specifically (1) Boulder, Colorado; (2) Quebec, Canada; and (3) the Bay Area Air Quality Management District, California.

239 Ibid at iv. Specifically (1) the United Kingdom; (2) British Columbia, Canada; and (3) France.

$240 \quad$ Ibid at iv. Specifically (1) Sweden; and (2) Norway.

241 "PM: Dion's carbon tax would 'screw everybody,"” CBC News (20 June 2008), online: CBC News Canada < http://www.cbc.ca/news/canada/story/2008/06/20/harper-carbon.html>; Rosenblum, supra note 213; The Green Shift, supra note 213.

242 See "Australians to pay special flood tax," CBC News (26 January 2011), online: CBC News <http:// www.cbc.ca/world/story/2011/01/26/australia-floods.html>; Henrik Selin \& Stacy D VanDeveer, eds, Changing Climates in North American Politics: Institutions, Policymaking, and Mutltilevel Governance (Cambridge: MIT Press, 2009) at 243; Avi Bar-Eli, “'Drought Tax’ to start next week,” Haaretz (9 July 2009), online: Haaretz < http://www.haaretz.com/print-edition/business/drought-tax-to-start-next-week$1.279644>$. 
climate change risk; (3) using contracts to encourage clients to engage in loss prevention; (4) developing new products to encourage the use of climate friendly technology; (5) changing investment portfolios to include more climate friendly businesses; (6) participating in carbon markets as an investor and an insurer; (7) minimizing their own carbon footprint; (8) educating customers about how to minimize climate-related risks; and (9) engaging in public policy discussions about these risks. ${ }^{243}$ In Canada, Feltmate and Thistlethwaite have further recommended: (1) incorporating expectations regarding future climate into the building code process; ${ }^{244}$ (2) identifying high priority risks linked with future extreme weather; ${ }^{245}$ (3) creating insurance and government incentives for homeowner risk reduction; ${ }^{246}$ (4) the adaptation of the FireSmart model for urban flood and wind; ${ }^{247}(5)$ the provision of disaster mitigation assistance in Canada; ${ }^{248}$ (6) educating homeowners and business on the role of insurance; ${ }^{249}$ and (7) developing better data to estimate the risk of severe weather damage. ${ }^{250}$

Clearly, without government intervention of some kind, the private insurance market, operating within the legal regime designed to protect its financial viability, will not be able to provide for all climate-related losses even if those exposed to such risks want to purchase insurance to cover those losses. And notwithstanding the external contribution to climaterelated loss in Canada and the theoretical promise of international law, any government intervention will need to be entirely domestic. It remains to be seen whether government intervention will indeed be forthcoming to protect Canadians from the anticipated high costs of uninsurable climate harms, and if so, in what form.

$243 \quad$ See Ross, Mills \& Hecht, supra note 16.

$244 \quad$ Feltmate \& Thistlethwaite, supra note 13 at 19.

245 Ibid.

$246 \quad$ Ibid at 21.

Ibid at 22. See also ibid at 94-97; "FireSmart," online: FireSmart Canada <https://www.firesmart canada.ca>.

$248 \quad$ Feltmate \& Thistlethwaite, ibid at 22.

$249 \quad$ Ibid at 25.

250 Ibid. 